\begin{tabular}{|l|c|c|c|r|}
\hline $\begin{array}{l}\text { Cuadernos de Investigación Geográfica } \\
\text { Geographical Research Letters }\end{array}$ & 2017 & N $^{\circ} 43(2)$ & pp. 467-496 & $\begin{array}{r}\text { ISSN 0211-6820 } \\
\text { eISSN 1697-9540 }\end{array}$ \\
\hline
\end{tabular}

DOI: http://doi.org/10.18172/cig.3236

(C) Universidad de La Rioja

\title{
DEGLACIATION OF THE NORTH CASCADE RANGE, WASHINGTON AND BRITISH COLUMBIA, FROM THE LAST GLACIAL MAXIMUM TO THE HOLOCENE
}

\section{J.L. RIEDEL*}

U.S. National Park Service, North Cascades National Park, Sedro-Woolley, WA 98284, USA.

\begin{abstract}
Glacial retreat from the North Cascade Range after the Last Glacial Maximum (LGM) at approximately $21 \mathrm{ka}$ until the end of the Pleistocene at $11.6 \mathrm{ka}$ was complex and included both continental and alpine glaciers. Alpine valley glaciers reached their maximum extent before $21.4 \mathrm{ka}$, then underwent a punctuated retreat to valley heads. In the south, beyond the reach of ice sheet glaciation, several end moraines were deposited after the LGM. Moraines marking a re-advance of alpine glaciers to $<5 \mathrm{~km}$ below modern glaciers were deposited from 13.7 to $11.6 \mathrm{ka}$. The Cordilleran Ice Sheet flowed south from near $52^{\circ}$ north latitude in British Columbia into the North Cascades. At its maximum size the ice sheet covered more than $500 \mathrm{~km}^{2}$ and had a surface elevation of $2200 \mathrm{~m}$ in upper Skagit valley. Deglaciation commenced about $16 \mathrm{ka}$ by frontal retreat of ice flanking the mountains. Surface lowering eventually exposed regional hydrologic divides and stranded ice masses more than $1000 \mathrm{~m}$ thick in valleys. Isolated fragments of the ice sheet disintegrated rapidly from 14.5 to $13.5 \mathrm{ka}$, with the pattern of deglaciation in each valley controlled by valley orientation, topography, and climate. Like alpine glaciers to the south, retreat of the ice sheet remnants was slowed by millennial scale climate fluctuations that produced at least one large recessional moraine, and multiple lateral moraines and kame terraces from elevations of 200-1400 $\mathrm{m}$ in most valleys. Large volumes of glacial meltwater flowed through the North Cascades and was concentrated in the Skagit and Methow rivers. Outburst floods from deep proglacial lakes spilled across divides and down steep canyons, depositing coarse gravel terraces and alluvial fans at valley junctions. Climate at the LGM was characterized by a mean summer temperature 6 to $7{ }^{\circ} \mathrm{C}$ cooler than today, and $40 \%$ lower mean annual precipitation. Persistence of this climate for thousands of years before the LGM caused a 750-1000 m decrease in alpine glacier equilibrium line altitudes (ELA). In the southern North Cascades at $16 \mathrm{ka}$, glacial ELAs were 500-700 m lower than today, and during advances from 13.7 to $11.6 \mathrm{ka}$ alpine glacier ELAs were 200-400 $m$ lower.
\end{abstract}




\section{Deglaciación de la Cordillera de las Cascadas del Norte, Washington y Columbia Británica, desde el Último Máximo Glaciar al Holoceno}

RESUMEN. El retroceso glaciar de la Cordillera de las Cascadas del Norte después del Último Máximo Glaciar (LGM), desde aproximadamente $21 \mathrm{ka}$ hasta el final del Pleistoceno (11.6 ka), fue complejo e incluyó tanto glaciares continentales como alpinos. Los glaciares de los valles alpinos alcanzaron su máximo avance antes de $21.4 \mathrm{ka}$, sometiéndose luego a un retroceso con interrupciones en las cabeceras de los valles. En el sur, más allá del alcance del manto de hielo, varias morrenas finales se depositaron después de la LGM. Morrenas que marcaron nuevos avances en glaciares alpinos a $<5 \mathrm{~km}$ por debajo de los glaciares modernos se depositaron entre 13.7 y $11.6 \mathrm{ka}$. El manto de hielo cordillerano fluyó hacia el sur desde cerca de $52^{\circ}$ de latitud norte en la Columbia Británica hasta la cordillera de las Cascadas del Norte. En su extensión máxima, la capa de hielo cubría más de $500 \mathrm{~km}^{2}$ y alcanzaba una elevación superficial de 2200 m en el valle superior de Skagit. La deglaciación comenzó alrededor de 16 ka por retroceso frontal del hielo que flanqueaba las montañas. La reducción de la capa superficial expuso divisorias hidrológicas regionales y masas de hielo aisladas en los valles con más de $1000 \mathrm{~m}$ de espesor. Fragmentos aislados de la capa de hielo se desintegraron rápidamente entre 14.5 y $13.5 \mathrm{ka}$, con el patrón de deglaciación en cada valle controlado por la orientación, la topografía y el clima. Al igual que los glaciares alpinos del sur, el retroceso de los restos de la capa de hielo estuvo controlado por fluctuaciones climáticas de escala milenaria que produjeron múltiples morrenas de recesión y terrazas kame desde elevaciones de 200 a 1400 m en la mayoría de los valles. Grandes volúmenes de agua de fusión fluyeron a través de las Cascadas del Norte, concentrándose en los ríos Skagit y Methow. Grandes avenidas (outbursts) procedentes de profundos lagos proglaciares circularon por cañones pendientes y depositaron terrazas compuestas por gravas gruesas y conos aluviales en las confluencias de valles. El clima en el LGM se caracterizó por una temperatura media de verano entre 6 y $7^{\circ} \mathrm{C}$ más fría que la actual, y una precipitación media anual un $40 \%$ menor. La persistencia de este clima durante miles de años antes del LGM, provocó un descenso en la altitud de la linea de equilibrio glaciar (ELA) entre 750-1000 m. En el sur de las Cascadas del Norte, hacia $16 \mathrm{ka}$, las ELAs glaciares se localizaron a 500-700 m por debajo de la actualidad, y a 200-400 m durante los avances de 13.7 a $11.6 \mathrm{ka}$.

Key words: Pleistocene, deglaciation, ice age, North Cascades.

Palabras clave: Pleistoceno, deglaciación, edad de hielo, Cascadas del Norte.

Received: 4 February 2017 Accepted: 28 March 2017

\footnotetext{
* Corresponding author: J.L. Riedel, U.S. National Park Service, North Cascades National Park, Sedro-Woolley, WA 98284, USA. E-mail address: jon_riedel@nps.gov
} 


\section{Introduction}

Glacial retreat from the North Cascade Range after the Last Glacial Maximum (LGM) at approximately $21.0 \mathrm{ka}(21,000$ calendar years ago $)$ until the end of the Pleistocene at $11.6 \mathrm{ka}$ was complex. It included both continental and alpine styles of glaciation, where ice advanced up some valleys and down others, only to reverse flow during retreat (Waitt and Thorson, 1983; Riedel et al., 2010). In lower Skagit valley Heller (1980) found evidence of three ice-flow directions in the last glaciation.

Extensive alpine cirque and valley glaciers $30-40 \mathrm{~km}$ long and several hundred meters thick dominated the mountains from 25.0 to $21.4 \mathrm{ka}$. In the north, the alpine glaciers were relatively small by the time of ice sheet glaciation several thousand years later (Mackin, 1941; Riedel et al., 2010). In the south, beyond the area inundated by the ice sheet, the retreat of alpine valley glaciers after 21 ka occurred by backwasting of termini up mountain valleys (Porter, 1976; Porter et al., 1983; Porter and Swanson, 1998).

The Cordilleran Ice Sheet flowed south from near $52^{\circ}$ north latitude in British Columbia into North Cascade valleys and reached a thickness of more than $1500 \mathrm{~m}$ along the $49^{\text {th }}$ parallel (Fig. 1; Daly, 1912; Wilson et al., 1958; Prest et al., 1968; Waitt and Thorson, 1983). Ice flowing across the Similkameen valley advanced into open Skagit, Pasayten, and Ashnola valleys from the north and northeast, and over the North Cascades divide into the Methow and Chelan valleys (Fig. 1; Prest, 1968; Waitt, 1972, 1975, 1977; Waitt and Thorson, 1983; Riedel, 2011). The Puget Lobe moved from west to east up the Chilliwack, Nooksack, lower Skagit and Stillaguamish valleys, and blocked the mouths of other mountain valleys farther south (Thorson, 1980; Heller, 1980; Booth, 1986a). Landforms and glacial erratics indicate that it reached $50 \mathrm{~km}$ up Skagit valley where it met ice flowing down Skagit valley near Rockport (Fig. 1; Riedel, 2011). The inter-lobate zone extended south to the Stillaguamish valley, where landforms and deposits identify the interaction of the two lobes.

The Puget Lobe reached its maximum extent about $16.3 \mathrm{ka}$ (Troost, 2016) and began to retreat within a few centuries (Porter and Swanson, 1998). Ice sheet deglaciation of the mountains was complicated by high local relief, three regional drainage divides, and marine influences on the western flank. Geologic mapping conducted in the past 70 years has identified recessional deposits that reveal the pattern of ice sheet deglaciation, but much of this remote, rugged landscape has not been mapped and the ages of most glacial landforms have not been determined. Several authors have published reviews of the glaciation in this region, including Davis and Mathews (1944), Crandell (1965), Waitt and Thorson (1983), Clague (1986, 1989), Porter et al. (1983), Ryder et al. (1991); Fulton (1991), Booth et al. (2004), Porter (2004), and Kaufman et al. (2004).

This summary combines information from these regional reviews, more detailed local reports, and new data to describe the spatial and temporal patterns of deglaciation within the North Cascades after the LGM. Most of the discussion focuses on the retreat of the ice sheet in the northern part of the range because the retreat of alpine glaciers in the south is well documented, even if the timing of recessional moraine formation is uncertain. The area of interest is between Puget Lowland on the west and the Okanogan River on the east, and from Snoqualmie Pass in the south to the headwaters of the Skagit River in the north (Fig. 1). 


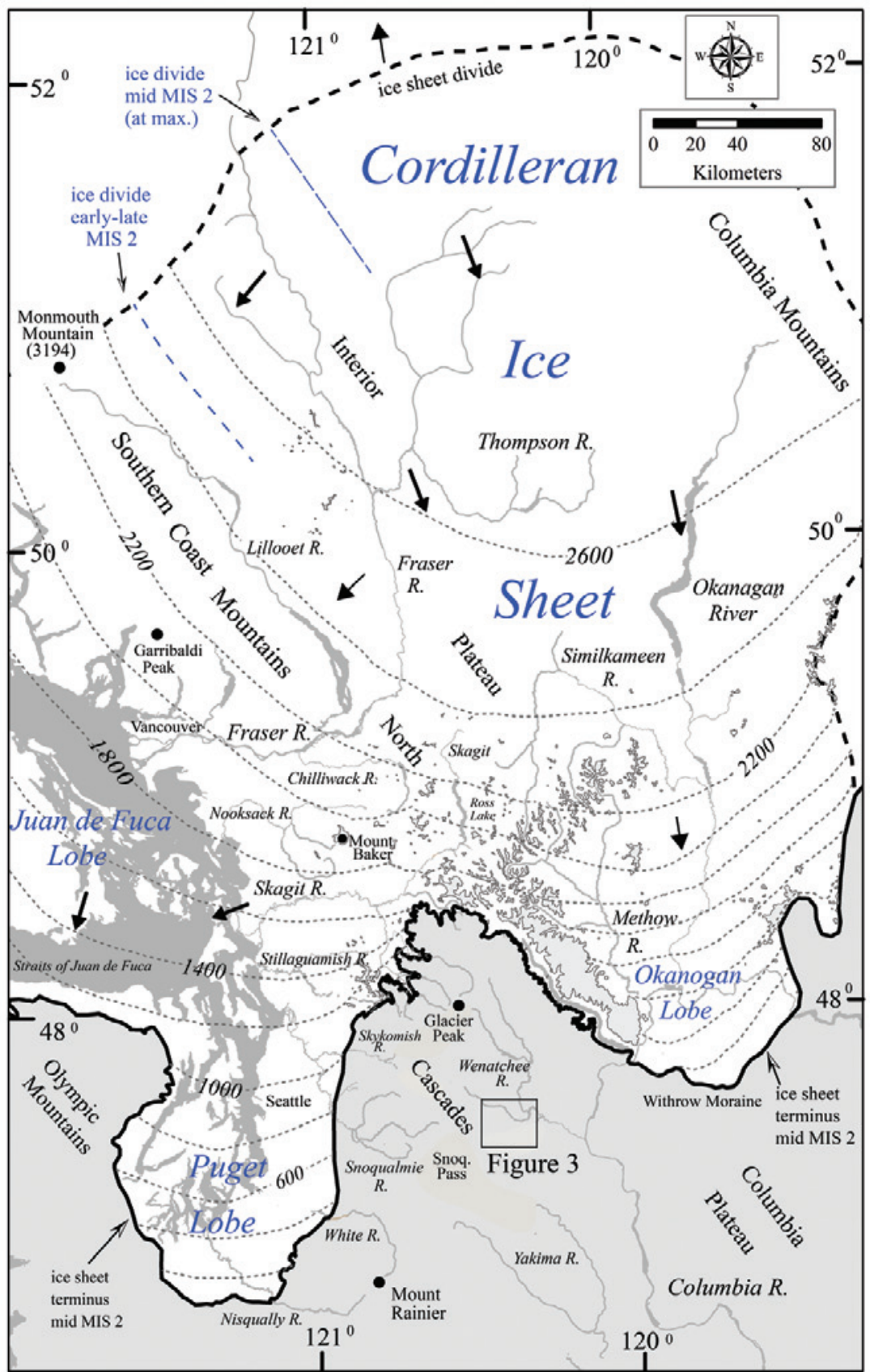

Figure 1. Maximum extent of the southwestern sector of the CIS at 16.3 ka reconstructed with data from Wilson et al.(1958), Prest et al.(1968), Waitt (1972, 1977, 1979), Waitt and Thorson (1983), Booth (1986), Clague et al. (1980, 1983, 1989), Ryder (1989), Kovanen and Slaymaker (2004), Riedel (2015), and Evans (written communication). Ice surface contour interval is $200 \mathrm{~m}$. 


\section{North Cascades physiography}

The North Cascade Range is distinguished from the Cascades farther south by several physiographic and geologic features. The North Cascades are generally higher and wider than the central and southern Cascades because they are located where the late Cretaceous-age Coast Mountains overlap with the Tertiary-age Cascades (Tabor and Haugerud, 1999). These two periods of orogeny caused intense deformation and metamorphism of previously accreted terranes. Cascade volcanic rocks associated with pluton intrusion have largely been stripped from the North Cascades by repeated, intense glacial activity (Mitchell and Montgomery, 2006).

Glacial erosion exposed high-grade metamorphic rocks such as gneiss and schist and intruded plutons in the core of the range and created a remarkable glacial landscape (Fig. 2). Horns, arêtes, cirques, and deep U-shaped valleys dominate the mountain landscape, where local relief exceeds $2000 \mathrm{~m}$. Alpine cirque and valley glaciers sculpted most of the erosional landforms, but the north also bears clear signs of ice sheet erosion (Waitt, 1977, 1979). Valleys trending parallel to the southward flow of the ice sheet were widened dramatically, while mountain passes were beveled. Ice sheet glaciation altered drainage patterns to produce long, interconnected valleys (Flint, 1971; Riedel et al., 2007). Breaching of high mountain divides and stream

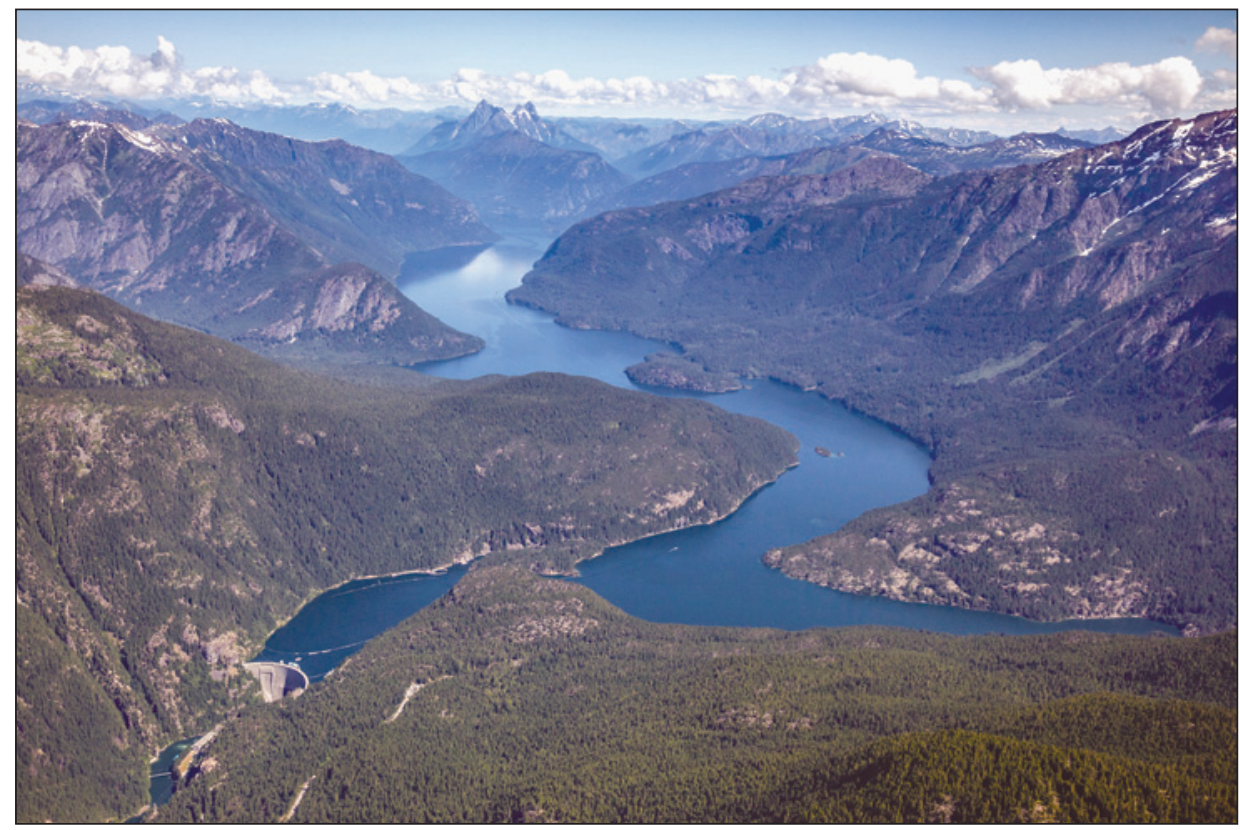

Figure 2. Upper Skagit valley and Ross Lake looking north to glacial horn Hozomeen Mountain $(2459 \mathrm{~m})$, a nunatak during full ice sheet glaciation. The CIS moved south from the Similkameen valley in British Columbia into the North Cascades, reaching a surface elevation of $2100 \mathrm{~m}$ (1500 m thick) over the valley floor. Upper Skagit valley was an unglaciated refuge during the LGM. Ross Dam at head of Skagit Gorge lower left, and flooded mouth of Ruby Creek lower right. Photo by John Scurlock. 
piracy by glacial lake spillover occurred early in the Pleistocene when initial ice sheet glaciation blocked drainage north into the Fraser and Okanogan rivers (Fig. 1; Simon-Labric et al., 2014). Divide elimination, focused on the lowest passes along the divides, led to stream piracy, reversal of dendritic drainage patterns, and beheading of valleys. Glacial rearrangement of drainage had a strong influence on the pattern of ice sheet deglaciation, particularly in the Skagit valley.

Hydrologic divides within the North Cascades are towering features isolated by intense glacial erosion (Fig. 2). There are three main hydrologic divides in the region that direct overland flow into the Fraser and Columbia rivers and Puget Sound (Fig. 1). These divides had a strong influence of the pattern of ice sheet deglaciation by separating large ice masses from their source areas to the north. Of particular interest are the North Cascades and Skagit crests, which bisect the region and have average elevations of $\sim 2000 \mathrm{~m}$. The Skagit and Pacific crests trend north-south parallel to the overall flow of the ice sheet. These divides separate more arid eastern valleys from the more humid west slope. Skagit crest runs parallel to the Pacific crest, isolates the upper Skagit valley, and is breached only at Skagit Gorge. The North Cascades crest runs west-east from Mount Baker to the Okanogan Highlands, perpendicular to flow of the ice sheet.

\section{Chronologic framework}

The regional chronostratigraphic framework for the last glaciation is based largely on ice sheet glaciation of the Puget and Fraser lowlands, has not been updated for more than 50 years, and does not accommodate the higher frequency activity of alpine glaciers (Armstrong et al., 1965). Considering these limitations, the period from the LGM to the end of the Pleistocene is divided into early, mid, and late marine isotope stage 2 (MIS 2) for the purpose of discussion where precise age limits are unavailable. The Fraser Glaciation covers the same interval as MIS 2, and is also referred to as the late Wisconsin (Armstrong et al., 1965). Early MIS 2 included the Evans Creek stade alpine glacier advance, and ended at the Port Moody interstade (Riedel et al., 2010). Mid MIS 2 was marked by the advance and retreat of the CIS during the Vashon stade, and ended in the lowlands during a marine incursion into western valleys during the Everson interstade (Dethier et al., 1995). Late MIS 2 was dominated by the final decay of the ice sheet in higher mountain valleys, and included late advances by the CIS (Sumas stade) (Clague et al., 1997) and alpine glaciers (Porter et al., 1983; Osborn et al., 2012).

Ages that limit the timing of deglaciation are presented as the mean age in thousands of calendar years before present rounded to the nearest century (e.g. $21.3 \mathrm{ka}$; Tables 1 and 2). Radiocarbon ages determined from 13 wood and two gyttja samples in and near the North Cascades provide the primary age control on deglaciation. Radiocarbon ages were calibrated using Oxcal 4.2 (Bronk Ramsay, 2009). Radiocarbon age estimates for deglaciation from Cranberry Lake and Kwoiek Lake are $15 \mathrm{ka}$ or older, which was 1,000 years or more before most other sites were ice-free (Souch, 1989; Kovanen and Easterbrook, 2001). These estimates have large uncertainties, however, that overlap with the younger wood chronology at $2 \sigma$ (Table 2 ). 
A few moraine ages have been estimated by cosmogenic surface dating of boulders (Porter and Swanson, 2008). Beryllium-10 dates were calibrated using the CRONUS program, while the Chlorine-36 surface exposure ages of alpine glacier moraines published in 2008 by Porter and Swanson were not recalibrated. A volcanic tephra erupted by Glacier Peak about 13.6 ka provides an important time-stratigraphic marker in the eastern North Cascades (Porter, 1978; Kuehn et al., 2009).

Table 1. Ages of late Pleistocene (MIS 2) alpine glacier moraines and deposits in the North Cascades.

\begin{tabular}{l|c|c|l}
\hline \multicolumn{1}{c|}{ Location } & $\begin{array}{c}\text { Age Type } \\
\text { (uncorrected age })\end{array}$ & $\begin{array}{c}\text { Calibrated Age* } \\
\text { (mean) }\end{array}$ & \multicolumn{1}{|c}{ Source } \\
\hline \multicolumn{4}{|c}{ Skagit } \\
\hline \multirow{2}{*}{ Lake Skymo } & ${ }^{14} \mathrm{C}(18,020 \pm 170)$ & $22.3-21.4(21.8)$ & Riedel et al. $(2010)$ \\
\hline \multirow{2}{*}{ Lake Concrete } & $(20,770 \pm 80)$ & $25.3-24.6(25.1)$ & ${ }^{14} \mathrm{C}(17,570 \pm 90)$ \\
& $(20,730 \pm 40)$ & $21.5-20.9(21.2)$ & Riedel et al. $(2010)$ \\
\hline
\end{tabular}

\begin{tabular}{l|l|l|l}
\hline Fisher Creek 3 & ${ }^{10} \mathrm{Be}$ & $14.5-9.4(11.9)$ & Riedel (2007) \\
\hline Arriva 3 & ${ }^{10} \mathrm{Be}$ & $16.4-13.6(15.0)$ & Riedel (2007) \\
\hline Arriva 4 & ${ }^{10} \mathrm{Be}$ & $13.4-11.0(12.2)$ & Riedel (2007) \\
\hline \multicolumn{4}{|c}{ Mt Baker } \\
\hline $\begin{array}{l}\text { Middle Fork } \\
\text { Nooksack }\end{array}$ & ${ }^{14} \mathrm{C}(10,510 \pm 50)$ & $12.6-12.3(12.5)$ & Scott (written communication) \\
\hline Rocky Creek & ${ }^{14} \mathrm{C}(10,980 \pm 70)$ & $13.0-12.7(12.9)$ & Kovanen and Easterbrook (2001) \\
\hline \multicolumn{4}{|c|}{ Wenatchee } \\
\hline Leavenworth I & $\mathrm{Cl}^{36}$ & $22.1-16.1(19.1)$ & Porter and Swanson (2008) \\
\hline Leavenworth II & $\mathrm{Cl}^{36}$ & $13.4-13.2(13.3)$ & Scott (written communication) \\
\hline
\end{tabular}

\begin{tabular}{l|l|c|l}
\hline Rat Creek I & $\mathrm{Cl}^{36}$ & $14.1-12.8(13.3)$ & Porter and Swanson (2008) \\
\hline Rat Creek II & $\mathrm{Cl}^{36}$ & $13.0-12.0(12.5)$ & Porter and Swanson (2008) \\
\hline Brisingamen & ${ }^{14} \mathrm{C}($ estimate $)$ & $>11.3$ & Bilderback and Clark (2003) \\
\hline \multicolumn{4}{|c|}{ Yakima } \\
\hline Domerie I & $\mathrm{Cl}^{36}$ & $24.2-21.2(23.2)$ & Kaufman et al. (2004) \\
\hline Domerie II & $\mathrm{Cl}^{36}$ & $17.9-14.7(16.3)$ & Kaufman et al. (2004)
\end{tabular}

\begin{tabular}{l|l|c|l}
\hline Hyak I & $\mathrm{Cl}^{36}$ & $14.6-13.6(14.1)$ & Porter and Swanson (2008) \\
\hline Hyak II & $\mathrm{Cl}^{36}$ & $13.5-11.9(12.7)$ & Porter and Swanson (2008) \\
\hline Hyak II (UW 321) & ${ }^{14} \mathrm{C}(>11,050 \pm 50)$ & $13.1-12.8(>13.0)$ & Porter (1976) \\
\hline
\end{tabular}

* Radiocarbon ages calibrated using the OxCal program and ${ }^{10} \mathrm{Be}$ ages calibrated using the CRONUS program show $2-\sigma$ range $(95.4 \%$ confidence). 
Table 2. Maximum limiting radiocarbon ages on retreat of the Cordilleran Ice Sheet from the northern North Cascades and adjacent areas.

\begin{tabular}{|c|c|c|c|}
\hline $\begin{array}{c}\text { Location - material } \\
\text { (Sample Lab Number) }\end{array}$ & $\begin{array}{c}\text { Radiocarbon } \\
\text { Age }\end{array}$ & $\begin{array}{l}\text { 20 Calibrated Age* } \\
\text { (mean and error) }\end{array}$ & Source \\
\hline \multicolumn{4}{|c|}{ Skagit } \\
\hline $\begin{array}{c}\text { Burlington Hill - wood } \\
\text { top GMD } \\
\text { (Beta-108959) } \\
\end{array}$ & $11,960 \pm 110$ & $14,088-13,556(13,815 \pm 138)$ & Dragovitch et al. 1998 \\
\hline $\begin{array}{l}\text { Sandy Cr. Mt. Baker - } \\
\text { wood in lake sediments. }\end{array}$ & $12,200 \pm 45$ & $14,241-13,951(14,091 \pm 72)$ & $\begin{array}{l}\text { Scott (written } \\
\text { communication) }\end{array}$ \\
\hline $\begin{array}{c}\text { Thunder Lake Core - } \\
\text { macrofossil } \\
\text { (CAMS-11196) }\end{array}$ & $11,780 \pm 180$ & $\begin{array}{l}14,060-13,271(13,639 \\
\pm 103)\end{array}$ & Spooner et al. (2007) \\
\hline \multicolumn{4}{|c|}{ Nooksack } \\
\hline $\begin{array}{l}\text { Lynden - tree stump } \\
\text { (Beta-1324) }\end{array}$ & $11,455 \pm 125$ & $13,415-13,181(13,298 \pm 117)$ & Dethier et al. (1995) \\
\hline $\begin{array}{l}\text { Kendall Moraine - wood } \\
\text { in GMD (B-1220447) }\end{array}$ & $11,910 \pm 80$ & $13,984-13,555(13,730 \pm 114)$ & $\begin{array}{l}\text { Kovanen and Easterbrook } \\
(2001)\end{array}$ \\
\hline $\begin{array}{c}\text { Deming Sand - tree stump } \\
(\mathrm{WW}-1)\end{array}$ & $11,500 \pm 200$ & $13,768-12,980(13,345 \pm 198)$ & Easterbrook (1976) \\
\hline $\begin{array}{c}\text { Deep Kettle Bog - wood } \\
\text { in peat (AA-21298) }\end{array}$ & $12,380 \pm 90$ & $14,940-14,095(14,463 \pm 225)$ & $\begin{array}{l}\text { Kovanen and Easterbrook } \\
(2001)\end{array}$ \\
\hline \multicolumn{4}{|c|}{ Chilliwack } \\
\hline $\begin{array}{c}\text { Slesse Creek - wood } \\
\text { (GSC3306) }\end{array}$ & $11,900 \pm 120$ & $14,032-13,473(13,731 \pm 148)$ & Saunders et al. (1987) \\
\hline $\begin{array}{l}\text { Post Creek - wood } \\
\text { (GSC-2966) }\end{array}$ & $11,700 \pm 100$ & $13,746-13,337(13,531 \pm 106)$ & $\begin{array}{l}\text { Clague and Luternauer } \\
(1982)\end{array}$ \\
\hline $\begin{array}{c}\text { Tamihi Slide - wood } \\
\text { (GSC4037) }\end{array}$ & $11,200 \pm 90$ & $13,252-12,827(13,053 \pm 104)$ & Saunders et al. (1987) \\
\hline \multicolumn{4}{|c|}{ Fraser } \\
\hline $\begin{array}{c}\text { Pinecrest Lake(320m) - } \\
\text { gyttja (I-5346) }\end{array}$ & $11,430 \pm 150$ & $13,570-13,020(13,277 \pm 140)$ & Mathewes et al. (1972) \\
\hline $\begin{array}{c}\text { Marion Lake - pine } \\
\text { needles }\end{array}$ & $11,920 \pm 245$ & $14,695-13,267(13,868 \pm 351)$ & Mathewes (1973) \\
\hline $\begin{array}{c}\text { Kwoiek Lake }(835 \mathrm{~m}) \text { - } \\
\text { cone }(\mathrm{S}-3010) \\
\end{array}$ & $12,555 \pm 770$ & $\begin{array}{l}17,231-13,079(14,960 \\
\pm 1083)\end{array}$ & Souch (1989) \\
\hline \multicolumn{4}{|c|}{ Okanogan } \\
\hline $\begin{array}{l}\text { Mud Lake - gyttja } \\
\quad(\text { TX-2690) }\end{array}$ & $11,490 \pm 560$ & $15,239-12,222(13,581 \pm 753)$ & Mack et al. (1979) \\
\hline $\begin{array}{c}\text { Monte Lake - Thompson } \\
\text { River (GSC 526) }\end{array}$ & $>9,750 \pm 170$ & $11,755-10,601(11,146 \pm 289)$ & Lowdon et al. (1967) \\
\hline \multicolumn{4}{|c|}{ Volcanic Tephra } \\
\hline Glacier Peak G tephra & $11,600 \pm 50$ & $13,710-13,410(13,560 \pm 150)$ & Kuehn et al. (2009) \\
\hline
\end{tabular}

* Calibration from OxCal 4.2 (Bronk Ramsay, 2009).

\section{Deglaciation of the North Cascades - Alpine glaciers}

Paleoecological and stratigraphic evidence indicate that the climate at the LGM from about 25.0 to $21.4 \mathrm{ka}$ was the coldest part of MIS 2 in this region (Barnosky et al., 1987; Grigg and Whitlock, 2002; Thackray, 2001, 2008; Riedel et al., 2010). Short, 
cool summers and long winters favored development of 30-40 km long alpine glaciers several hundred meters thick in valleys (Porter, 1976; Waitt, 1977; Heller, 1980; Porter et al., 1983; Riedel et al., 2010). The valley glaciers were limited in extent, however, and parts of some major mountain valleys were ice-free refugia during this period (Riedel, 2007). In Skagit valley, the radiocarbon ages listed in Table 1 were recovered from wood encased in glacial lake beds, and constrain the timing of alpine glacier advances in the Baker (Lake Concrete) and Big Beaver (Lake Skymo) valleys (Riedel et al., 2010).

In the north, valley glaciers began to retreat by $21.4 \mathrm{ka}$ during the Port Moody interstade, and had retreated upvalley by the time of full ice sheet glaciation at 16.3 ka (Lian et al., 2001; Mackin, 1941; Porter, 1976; Riedel et al., 2010). Glacial retreat was likely enhanced by the influence of the growing ice sheet on climate (Grigg and Whitlock, 2002; Thackray, 2001, 2008). In the northern part of the range, most of the recessional moraines and outwash deposits left by retreating valley glaciers were later destroyed or buried by the ice sheet. Small pockets of alpine drift were preserved in gullies on the down-ice side of valley spurs and near terminal areas in Skagit valley (Riedel et al., 2010).

In the southern North Cascades beyond the direct influence of the CIS, Porter (1976) and others mapped alpine glacier moraines in the Snoqualmie, Yakima, and Wenatchee valleys (Fig. 1 and 3). Porter and Swanson (2008) used cosmogenic dating of boulders to determine moraine ages, but the estimates have large errors due to uncertainty in isotope production rates, inherited exposure, and other factors (Table 1). The outer Leavenworth I and closely nested Leavenworth II moraines' boulders have average exposure ages of 19.1 and 17.1ka, respectively. The authors suggest that the true age of the older moraine may be closer to the oldest sample age of $24.7 \pm 1.1 \mathrm{ka}$. If that interpretation is correct, the Leavenworth I moraine was deposited at the same time as alpine advances in the Skagit, Yakima (Domerie I) and Hoh (Twin Creeks I) valleys, at about the same time as the LGM (Table 1; Thackray, 2001; Kaufman et al., 2004; Riedel, et al., 2010). The Leavenworth II moraine age estimate is roughly the same age as the Domerie II moraine in the Yakima valley, and they were deposited at about the same time as the culminating advance of the CIS at $16.3 \mathrm{ka}$ (Table 2; Kaufman et al., 2004; Porter and Swanson, 2008; Troost, 2016). Porter (1976) concluded that five closely-nested end moraines near Bandera in the upper Snoqualmie River valley were also deposited about this time. Until more accurate age determinations are made for more moraines, the alpine glacier chronology from the LGM to 13.7 ka remains tentative.

After the deposition of the Leavenworth, Domerie, and Bandera moraines, alpine glaciers retreated before re-advancing in mid-to-late MIS 2. The Rat Creek and Hyak I moraines in the upper Wenatchee and Yakima valley represent advances of alpine glaciers at this time, but Chlorine-36 age estimates have large errors (Fig. 1 and 3; Table 1). Given the $600 \mathrm{~m}$ depression in equilibrium line altitude necessary to build glaciers out to these moraines, and the age of the Brisingamen moraine, the true age of the Rat Creek moraines is probably slightly older than 14.0 ka (Table 1; Porter et al., 1983). In the upper Wenatchee valley, Glacier Peak G tephra was used to map the extent of Rat Creek age glaciers (Fig. 1; Porter, 1978). At the time of the 13.6 ka eruption, alpine glaciers at all of these sites were within $5 \mathrm{~km}$ of cirque basins and valley heads. 
The alpine glacier chronology late in MIS 2 is better established by radiocarbon dating at several sites. Porter (1976) recovered a $13.0 \mathrm{ka}$ age on wood over-ridden by the Hyak II advance near Snoqualmie Pass (Fig. 1; Table 1). A sediment core from Enchantment Lake indicates that the Brisingamen moraines, located in a cirque above the Rat Creek moraines, were deposited before 11.3 ka (Fig. 3; Bilderback and Clark, 2003). Alpine glaciers in areas inundated by the ice sheet also underwent late MIS 2 advances even as remnants of the ice sheet remained in some valleys. Several Mount Baker alpine glaciers advanced off of the volcano and into forests. The innermost of four end moraines below Deming Glacier was deposited about 12.8 ka (Table 1; Kovanen and Easterbrook, 2001; Osborn et al., 2012). A lateral moraine below Easton Glacier is older than a volcanic tephra and charcoal on the moraine that have ages of $13.4 \mathrm{ka}$ and $13.2 \mathrm{ka}$, respectively (Scott, written communication). Granite boulders on end moraines in upper Skagit valley were dated with the Beryllium-10 method at 15.0 and $12.2 \mathrm{ka}$ at Arriva Creek, and 11.9 ka at Fisher Creek (Table 1; Fig. 4; Riedel 2007). Like the Chlorine-36 age determinations to the south, these estimates all have large errors, making their correlation with the Mount Baker, Hyak, and Brisingamen moraines tentative.

These late MIS 2 alpine moraines are all within $5 \mathrm{~km}$ of valley heads and have similar ages to moraines in the Olympic Mountains (Thackray, 2001), Mount Rainier (Heine, 1998), the Rocky Mountains (Reasoner et al., 1994), the Wallowa Mountains (Kiver, 1974), the Wind River Range (Gosse et al., 1995; Zielinski and Davis, 1987), and the southern Coast Mountains (Friele and Clague, 2002). Many authors have correlated these regional late glacial advances to the Older and Younger Dryas cold periods in

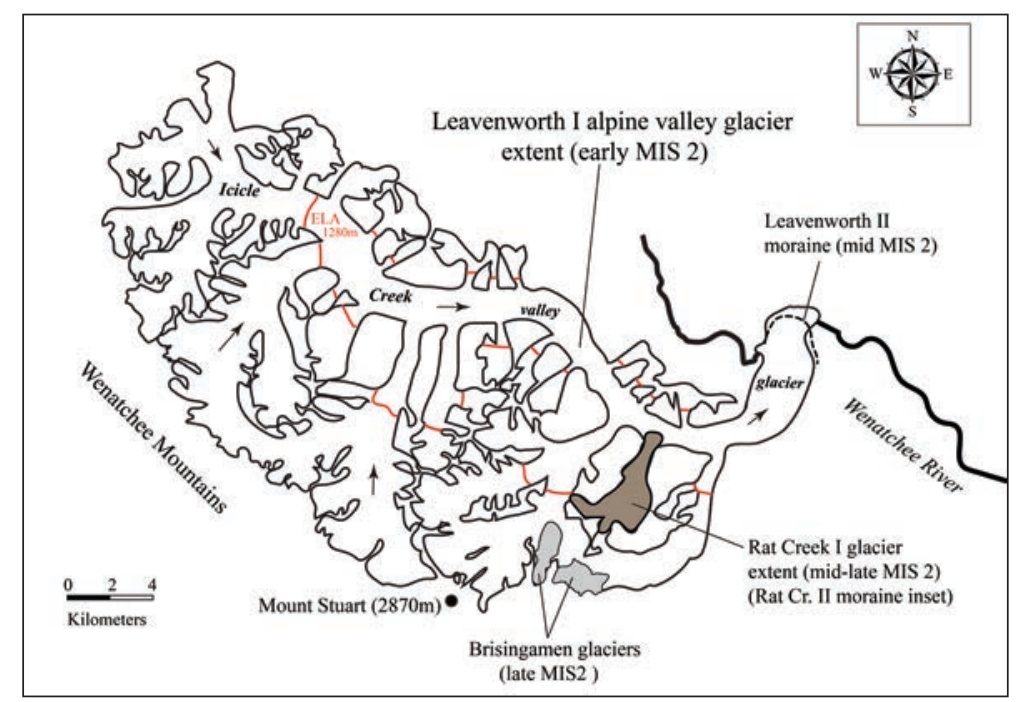

Figure 3. Marine isotope stage 2 extents of alpine cirque and valley glaciers in the Icicle Creek valley. Modified from Porter and Swanson (2008) and Bilderback and Clark (2003). Note Rat Creek and Brisingamen reconstructions only completed for one tributary system (all tributaries also hosted alpine glaciers). 
northern Europe from 14.1 to $11.6 \mathrm{ka}$ (Stuiver et al., 1995; Clague et al., 1997; Friele and Clague, 2002; Kovanen and Slaymaker, 2005; Riedel, 2007; Osborn et al., 2012).

\section{Deglaciation of the North Cascades - Cordilleran Ice Sheet}

Invasion of the North Cascade Range by the south-flowing Cordilleran Ice Sheet (CIS) during mid MIS 2 was out of phase with the alpine glacial maximum several thousand years earlier (Cary and Carlston, 1937; Mackin, 1941; Riedel et al., 2010). In the part of the range inundated by the CIS, this meant that local alpine glaciers were not significant contributors to the volume of the ice sheet. As evidence, erratic boulders transported by the CIS occur in cirques and valley heads in the Methow and Pasayten valleys (Waitt, 1972, 1975; Waitt and Davis, 1988) and at the base of the Mount Baker volcanic edifice.

At the CIS maximum, the ice surface stood at an elevation of 2000-2200 m over the drainage divides, with a higher ice surface in the east and a thickness of $1500 \mathrm{~m}$ over upper Skagit valley (Fig. 1). As little as $200 \mathrm{~m}$ of ice surface lowering would have exposed the divides and stranded ice masses more than $1000 \mathrm{~m}$ thick in valleys. The ice surface gradient of $10-15 \mathrm{~m} / \mathrm{km}$ through the North Cascades was relatively low due to high sliding velocity of the ice sheet (Booth, 1986a; Evans, written communication). The low surface gradient caused rapid ice surface lowering over a large area in a short amount of time during deglaciation. Evidence of early divide exposure in the North Cascades includes up-valley sloping lateral moraines, and kame terraces and meltwater canyons through mountain passes (Haugerud, 1985; Waitt, 1972, 1977; Riedel et al., 2007).

Ice sheet deglaciation in the western North Cascades was strongly influenced by events in southern British Columbia and in Puget Lowland (Fig. 1). The basic pattern of ice retreat to the north was summarized by Davis and Mathews (1944), Fulton (1967, 1991) and Clague (1989). Deglaciation occurred initially by downwasting from highlands, then from plateaus, and eventually by backwasting in valleys toward early centers of growth (Margold et al., 2013). The top-down pattern of retreat left some cirques ice-free before valleys. Ice that invaded the North Cascades flowed over the Thompson Plateau, and ice stagnation there had a direct effect on ice recession in the adjacent Skagit and Pasayten valleys.

Deglaciation of the North Cascades differed from the British Columbia model because the mountain valleys were near the terminus of the ice sheet and contained several regional hydrologic divides that resulted in large masses of ice stranded in most valleys. The stranded ice masses were too large to reach an equilibrium state under prevailing climate, and had relatively small, ineffective accumulation zones. Their disintegration was therefore controlled by the influence of valley orientation, topography, and climate. Ice in this setting retreated by rapid downwasting over a wide area and by backwasting (Waitt, 1972). Retreat of the CIS remnants within mountain valleys was punctuated by still-stands that left at least one large recessional moraine and multiple smaller lateral moraines and kame terraces in most valleys. Ice-marginal landforms are typically found at valley junctions where changes in valley floor elevation (hanging valleys) or valley orientation influenced ablation. 
Rapid lowering of the ice surface over northern Puget Sound caused flow of the ice sheet to change on the west flank of the range during deglaciation (Polenz et al., 2005). The lower ends of several valleys were briefly flooded by marine waters before being isostatically uplifted (Thorson, 1980; Dethier et al., 1995). These events caused rapid changes in CIS sedimentation, geometry and flow direction (Fig. 1; Porter and Swanson, 1998; Haugerud and Hendy, 2016). Clague and Ward (2011) found evidence that a marine-influenced pattern of deglaciation extended north along the western valleys of the Southern Coast Mountains in B.C.

Remnants of the CIS stranded in mountain valleys blocked drainage and created large proglacial lakes in valleys draining to the north. The Sauk, Chilliwack, Pasayten, and others hosted lakes dammed by retreating remnants of the ice sheet (Mathews, 1968; Clague and Luternauer, 1982; Tabor et al., 2002; Riedel et al., 2007). Proglacial lakes were generally short lived, and the timing of lake formation and outburst flooding is poorly known. Lakes generally migrated north against the retreating ice, occupying multiple outlets and producing a different history in each valley. Glacial lakes persisted in the upper Okanagan and Thompson valleys until as late as $11.1 \mathrm{ka}$, but by that time they did not drain across divides into the North Cascades (Table 2; Fulton 1967).

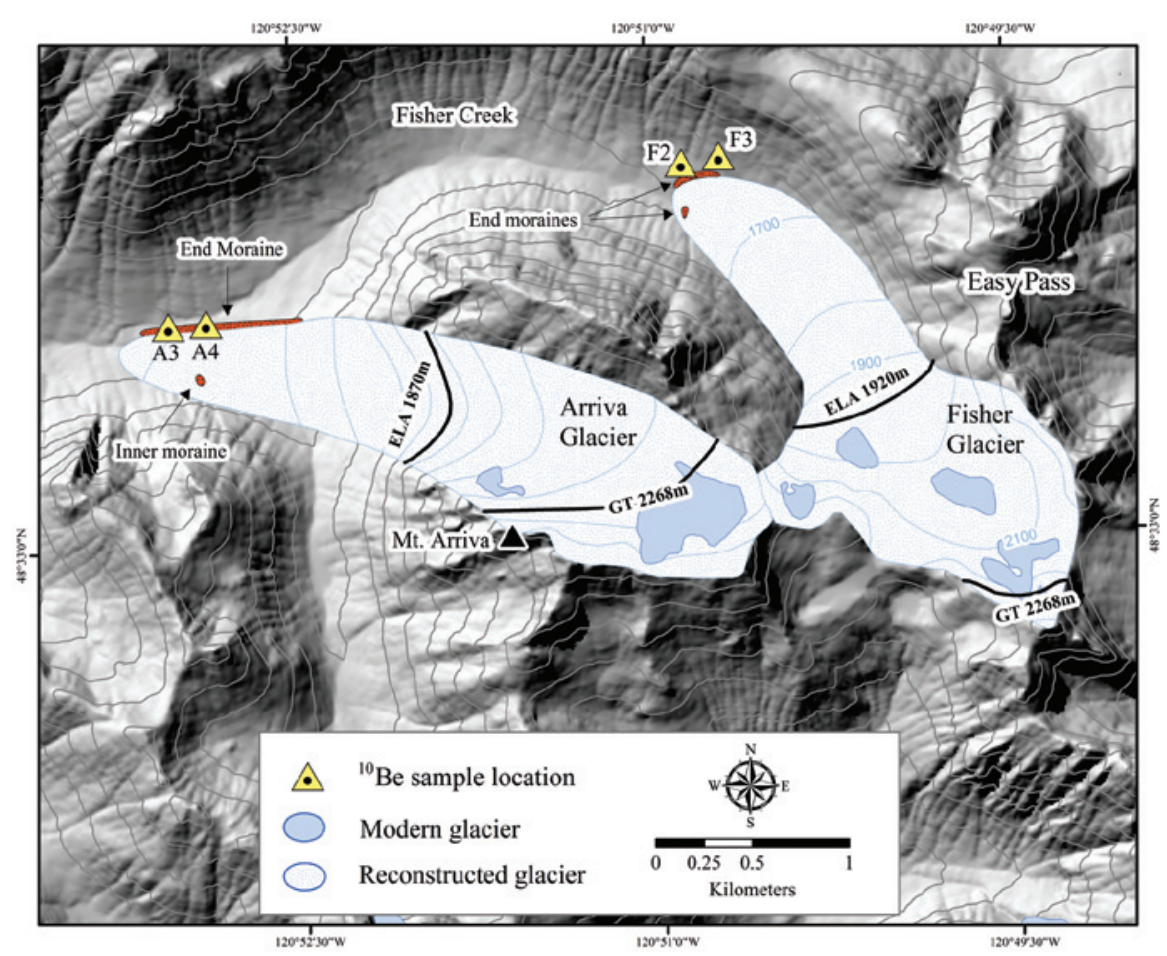

Figure 4. Late MIS 2 alpine glaciers and reconstructed ELAs in upper Fisher Creek, a Skagit River tributary (location shown in Fig. 5A). GT is glaciation threshold from Porter (1977) and is considered close to the mid-20th century ELA. 
CIS deglaciation began about $16 \mathrm{ka}$ when the Puget Lobe began to retreat from Puget Lowland (Troost, 2016). The subsequent chronology of ice retreat differed to some extent in each of the mountain valleys. Areas near the terminus in the south generally became ice-free earlier than in the northern part of the mountains where the ice was hundreds of meters thicker (Fig. 1). Initial retreat occurred rapidly in the Chelan valley and Puget Lowland because ice terminated in deep proglacial lakes (Bretz, 1910; Waitt and Thorson, 1983). Ice sheet deglaciation lasted several thousand years after 16.0 $\mathrm{ka}$, but the greatest loss of ice in the mountains was from 14.5 to $13.5 \mathrm{ka}$ (Table 2). Landforms and deposits left during ice decay and their approximate ages are discussed below in three groups determined by valley orientation relative to the CIS and include valleys facing away from (Chelan and Methow), toward (Pasayten and upper Skagit), and adjacent to the ice source (lower Skagit, Nooksack and Chilliwack).

\subsection{Chelan and Methow Valleys}

The CIS reached its southernmost extent on the east slope of the North Cascades in the Chelan and Methow valleys (Fig. 1 and 5A; Waitt and Thorson, 1983). Ice flowed into the Chelan valley from the Skagit through Fisher and Rainy passes, and eventually met ice coming up the valley from the Columbia River near Manson (Dawson, 1898; Waters, 1933; Whetten, 1967; Tabor et al., 1987; Waitt et al., 1994). During early stages of deglaciation, lowering of the ice sheet surface exposed the North Cascades crest, making these the first valleys isolated from the ice source to the north. Retreat of ice stranded in Chelan valley is not well-documented due to the narrow valley's steep walls and $450 \mathrm{~m}$ deep, $90 \mathrm{~km}$-long Lake Chelan (Fig. 5A). The CIS and its meltwaters played a role in carving the basin more than $100 \mathrm{~m}$ below sea level. Sub-bottom surveys of the lake bed have shown that glacial and postglacial sediments are $100 \mathrm{~m}$ thick near the mouth of Railroad Creek and 170 m thick in the Wapato Basin at the south end of the lake (Whetten, 1967; NPS, unpublished data).

Ice retreated up Chelan valley leaving scattered evidence of ice margins to its headwaters (Fig. 5A; Waitt and Thorson, 1983; Riedel and Probala, 2005). Landforms include a prominent, several-kilometer-long kame terrace near Grade Creek, and smaller terraces and moraines across the mouths of other valleys along Lake Chelan (Fig. 5A). Ice terminated near $380 \mathrm{~m}$ elevation in the lower Stehekin valley as marked by a large lateral moraine on the north side of the valley. The wasting ice also left several lateral moraines near valley junctions in Bridge Creek, but the time of deposition is unknown. Porter (1978) used the absence of Glacier Peak G tephra to infer that ice remained in the Chelan valley above Railroad Creek at the time of the 13.6 ka eruption (Fig. 5A; Table 2; Kuehn et al., 2009). Recent discovery of this tephra in mountain lakes to the north suggests that the ice may have retreated much farther up Chelan valley at this time.

Proglacial and ice-marginal lakes formed in the Methow and Chelan valleys during initial deglaciation. Lake Chelan drained southwest across a high divide down two canyons into the Columbia valley (Fig. 5A; Runner, 1921; Waters, 1933). The higher outlet was Navarre Coulee (canyon), which heads in a dry falls at $550 \mathrm{~m}$ elevation, more than $200 \mathrm{~m}$ above the modern surface of Lake Chelan. The lower outlet was Knapp 


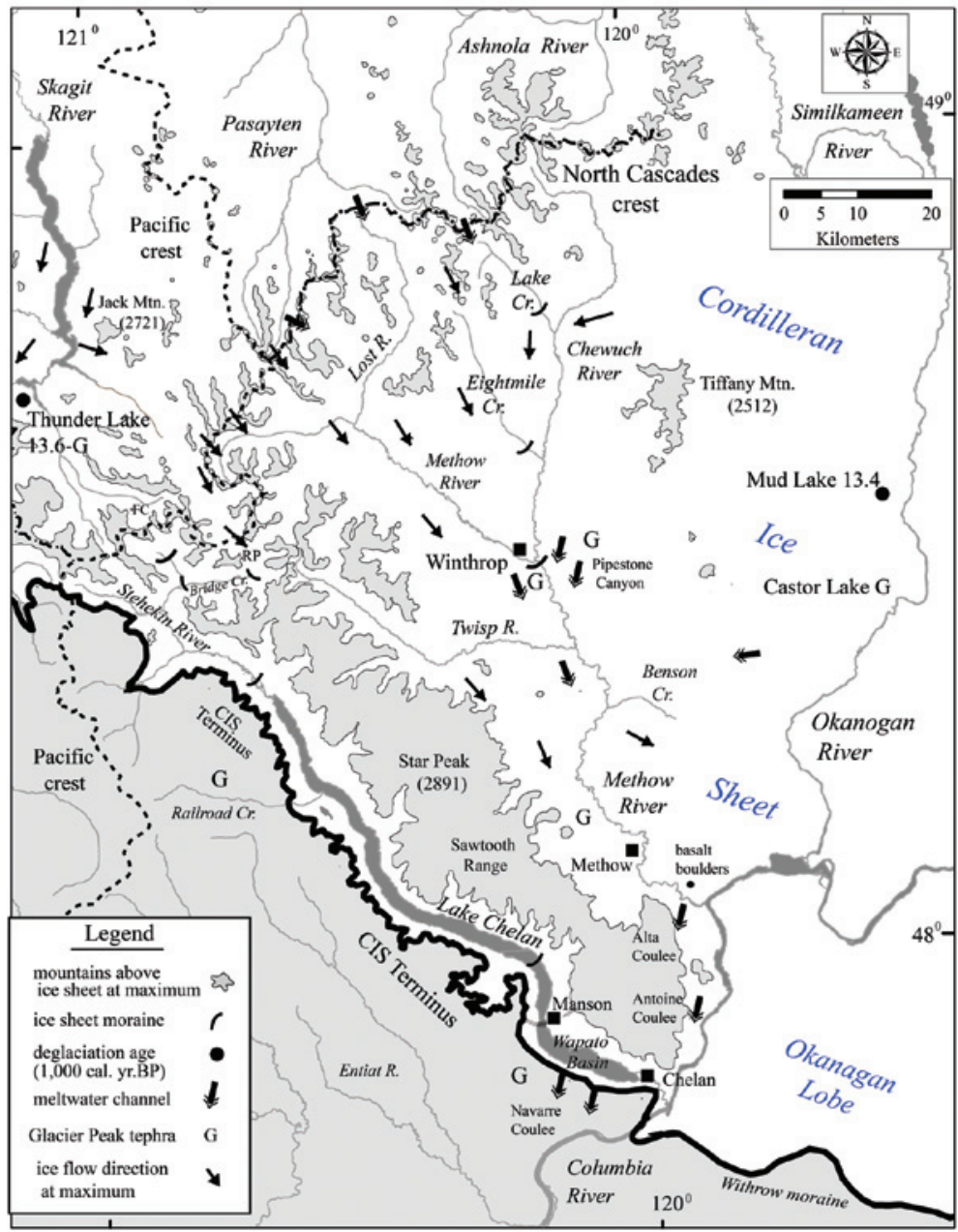

Figure 5A. Landforms created by the CIS in the northeastern North Cascades after its maximum extent about $16.3 \mathrm{ka}$. See Figure 1 for ice sheet surface contours. High-elevation ice flow indicators in Methow from Waitt (1972), in Ashnola from Ryder (1989) and in Skagit from Riedel (unpublished). Rainy Pass (RP) and Fisher Creek (FC-Fig. 4) discussed in text. Sources and data for deglaciaton ages in Table 2.

Coulee, which heads at $436 \mathrm{~m}$ and follows a similar path southwest to the Columbia River. After the CIS retreated north, opening the lower Chelan valley, glacial Lake Brewster occupied a segment of the Columbia River valley above Chelan Falls (Waitt and Thorson, 1983). Deposits from this lake are exposed on the east bank of Lake Pateros. Lake Brewster increased base-level of the Methow River and caused deposition of outwash terraces that are now perched high above the valley floor (Waitt and Thorson, 1983). Glacial Lake Brewster ceased existence once late MIS 2 floods as deep as $215 \mathrm{~m}$ from glacial Lake Columbia eroded away sediments damming the valley (Waitt et al., 1994). 
Meltwater canyons are also found throughout the Methow valley, and as elsewhere in the region many formed during pre-MIS 2 glaciations (Fig. 5A; Waitt, 1972; Riedel et al., 2007). Alta Coulee was the head of an ice marginal drainage system in the lower Methow linked by Antoine Coulee to the mouth of Chelan valley (Fig. 5A). Numerous other large meltwater canyons are found in the middle and upper Methow, but not all were active during the last deglaciation (Waitt, 1972). It is not clear when water coursed through these glacial drainage networks, but the Methow valley floor was not open until after the $13.6 \mathrm{ka}$ age for the deglaciation of Winthrop (Table 2).

Barksdale (1941) identified four CIS recessional moraines between Winthrop and Libby Creek in the Methow valley. Waitt (1972) suggested that some of the moraines were not recessional moraines, but were instead kame and outwash terraces marking former ice margins. The prevalence of these landforms and ice-marginal channels depicted a rapidly downwasting ice surface and large volumes of ice-marginal drainage (Waitt and Thorson, 1983). Evidence of a backwasting ice margin is absent in the narrow lower Methow valley, and the first large recessional moraine was deposited near Winthrop (Fig. 5A; Barksdale, 1941; Waitt, 1972). The Winthrop moraine is the largest in the Methow valley and contains numerous smaller lateral moraines, kettles, ice-marginal channels, and eskers. Waitt and Thorson (1983) described several smaller moraines and kame terraces in the upper Twisp, Chewuch, and Methow valleys.

No radiocarbon ages have been reported to constrain the age of the moraines and outwash terraces in the Methow. Porter (1978) did not find Glacier Peak ' $G$ ' tephra in the upper valley, implying that the area was deglaciated after the 13.6 ka eruption. The tephra has recently been discovered in a number of more northern sites across the North Cascades, from Thunder Lake to Castor Lake just west of the Okanogan River (Fig. 5A). Discovery of the tephra in Little Twin Lake on the Winthrop moraine provides the only limiting age for deglaciation of the upper Methow valley (Kuehn et al., 2009; M.B. Abbott, written communication).

\subsection{Pasayten and upper Skagit Valleys}

Initial deglaciation of the North Cascades exposed high-elevation terrain (Fig. 2). Evidence of top down retreat was discovered at two sites in upper Skagit valley. Lateral moraines that descend into upper Perry and Maselpanik creeks are clear evidence of ice retreating down small valleys from the Skagit crest (Fig. 5B; Haugerud, 1985; Riedel and Probala, 2005). Short water-cut canyons incised into mountain passes are found at the headwaters of these rivers along all three regional divides, showing that the passes were ice-free before some valleys (Waitt, 1972, 1979).

The Skagit and Pasayten valleys had somewhat different patterns of ice recession than the Chelan and Methow valleys because they face in the opposite direction, into, rather than away from, the flow of the CIS (Fig. 5B). This setting led to formation of proglacial lakes and landforms associated with lake drainage as the CIS terminus backwasted to the north. A landslide across a distributary lobe of the ice sheet in the upper West Fork of the Pasayten valley is evidence of a backwasting ice margin (Fig. 5B; Waitt, 1979). 


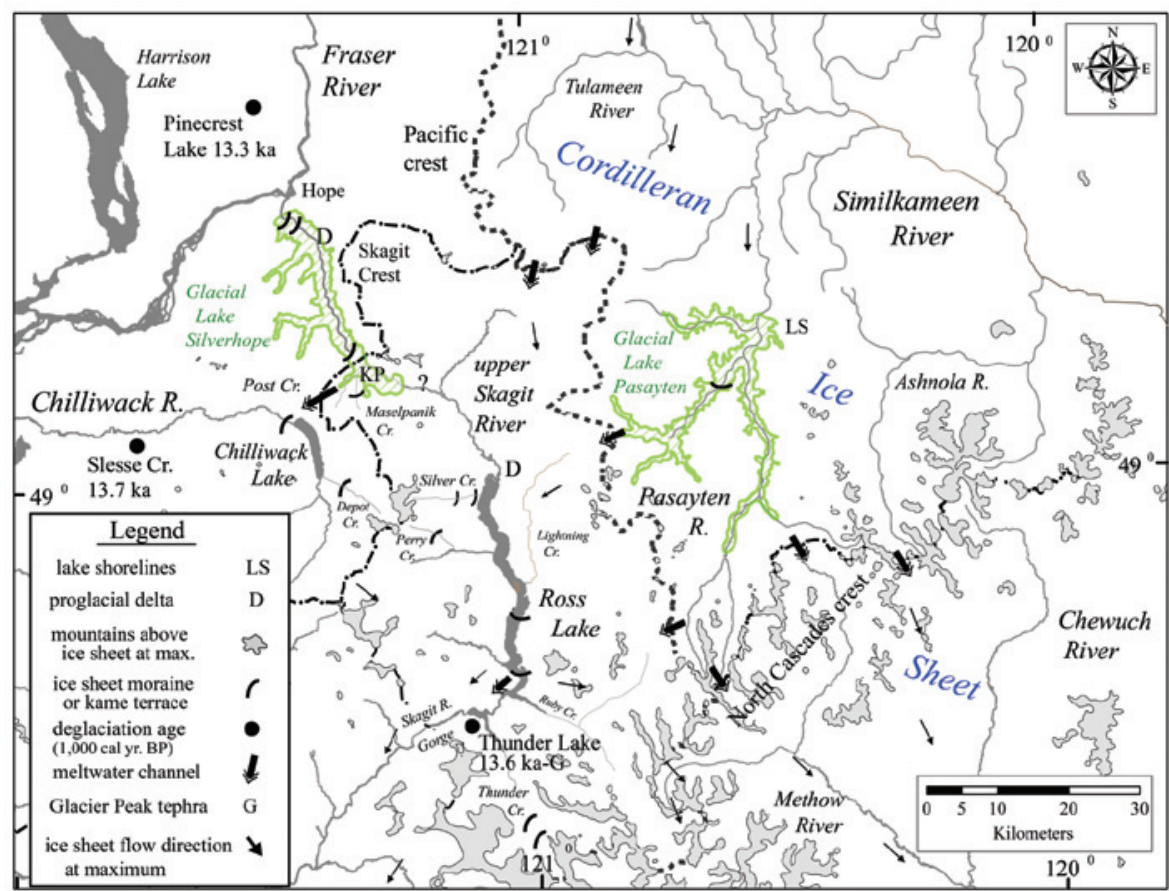

Figure 5B. Landforms created by the CIS in the northeastern North Cascades after its maximum extent about $16.3 \mathrm{ka}$. See Figure 1 for ice sheet surface contours. High-elevation ice flow indicators in Methow from Waitt (1972), in Ashnola from Ryder (1989), and in Skagit from Riedel (2015). Note terminus to the south of map area and all valleys filled with ice. Glacial Lake Silverhope shown with surface of $1000 \mathrm{~m}$ (Goff 1993) and Lake Pasayten $1300 \mathrm{~m}$ (Holmes, 1965). Klesilkwa Pass (KP) discussed in text. Sources and data for deglaciaton ages in Table 2.

Deglaciation of the upper Skagit valley followed a similar pattern with an ice margin retreating to the north. Evidence includes a small lateral moraine near Rowland Creek, kame terraces, ice-marginal channels, and an ice-proximal outwash terrace that slope to the south (Fig. 5B). At least one large recessional moraine has been mapped in most Skagit River tributaries (Riedel and Probala, 2005). A large end moraine at the mouth of Silver Creek and a kame-terrace lateral moraine complex $2.5 \mathrm{~km}$ farther up valley mark the extent and surface slope of the CIS valley remnants at two points in time (Fig. 5B). The ages of these and most other landforms created during deglaciation have not been determined.

Upper Skagit and lower Pasayten valleys held large proglacial lakes during CIS retreat. Holmes (1965) identified lake strand lines in the lower Pasayten valley at $1310 \mathrm{~m}$ elevation (Figs. 5B and 5C). Late MIS 2 drainage of glacial Lake Pasayten swept down Lightning Creek and into Skagit valley, leaving a massive alluvial fan at the junction of the two valleys (Fig. 5B; Mathews, 1968; Riedel et al., 2007). Lost River and Holman Pass were also outlets for drainage of Lake Pasayten when it had a higher surface elevation (Fig. 5B; Waitt, 1972; Riedel et al., 2007). 


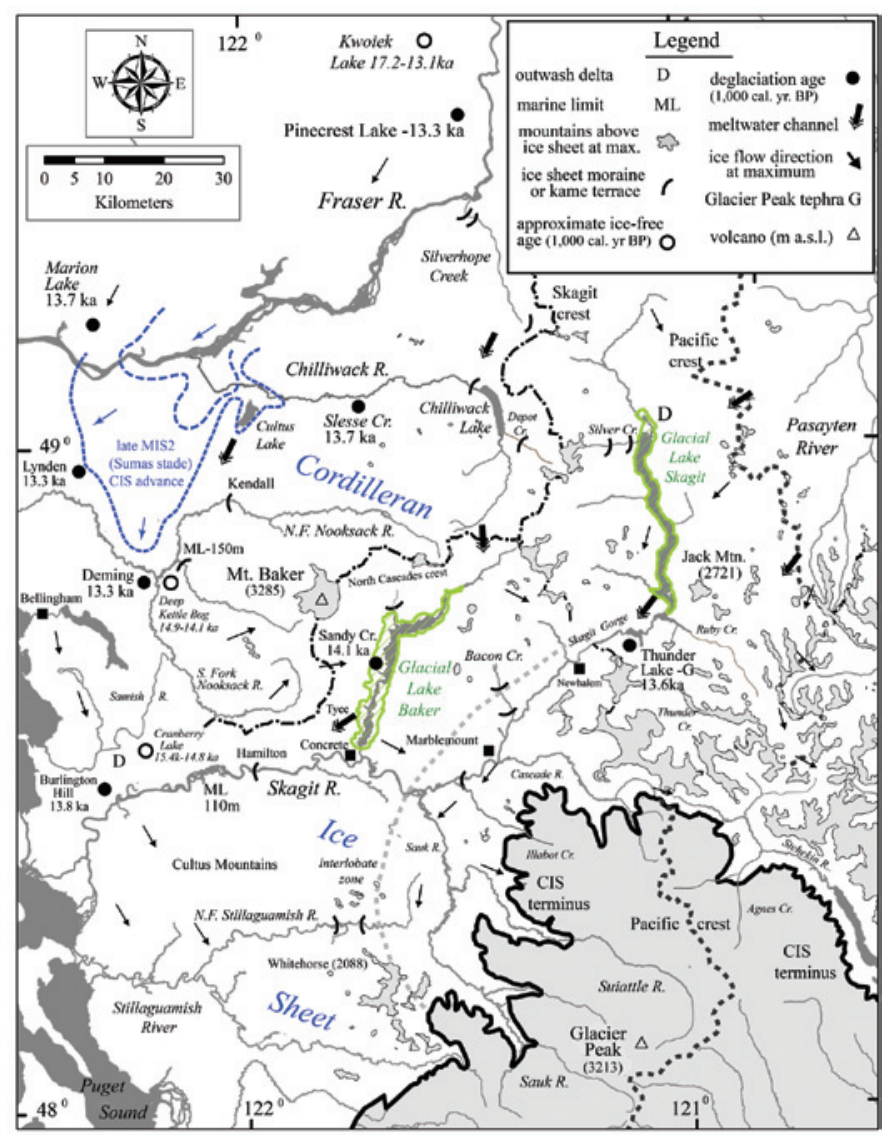

Figure 5C. Landforms created by the CIS in the northwestern North Cascades after its maximum extent about $16.3 \mathrm{ka}$. See Figure 1 for ice sheet surface contours. High-elevation ice flow indicators in Baker from Ragan (1961) and Heller (1980), in Skagit from Riedel (2015) and Waitt

(1977), and in British Columbia from Prest et al. (1968), Clague (1989), and Evans (written communication). Glacial Lake Baker shown at surface elevation of 335 m (Tyee outlet; Riedel et al. 2011) and Lake Skagit at $500 \mathrm{~m}$. Sources and data for deglaciaton ages in Table 2.

A gravel delta with steeply dipping fore-set beds was deposited near the head of modern Ross Lake in glacial Lake Skagit during deglaciation (Fig. 5C). The top of the delta had an elevation of about $512 \mathrm{~m}$, the same height as the head of a perched meltwater canyon at the other end of Ross Lake. The head of the canyon is a dry falls that controlled the elevation of glacial lake Skagit, probably when ice flowing west out of Ruby Creek blocked Skagit valley, displacing drainage into the west valley wall.

The Skagit River was a regional focal point for drainage of proglacial meltwater from most other major valleys in the region (Fig. 5B and 5C; Riedel et al., 2007). Proglacial lakes drained into the Skagit from the Chilliwack, Fraser, Tulameen, Similkameen, and Pasayten valleys at various times (Fig.s 5B and 5C; Mathews 1968; Riedel et al., 2007). It 
is not known when these various meltwater pulses occurred during the last deglaciation, but Skagit Gorge was not open until the deglaciation of Thunder Lake shortly before 13.6 ka. Glacial Lake Skagit ceased to exist before outburst flooding down Lightning Creek.

Ice backwasting to the north out of Skagit valley entered Silverhope Creek, a small steep stream draining north to the Fraser River (5C). Goff (1993) identified a minor readvance and two smaller still-stands of the CIS in this valley. A moraine at Klesilkwa Pass represents an advance of south-flowing ice that overrode stagnant ice buried in outwash. Klesilkwa Pass is a low-elevation divide separating the Fraser and the Skagit basins (Fig. 5C). Two kame terraces southwest of Hope record an ice margin sloping up Silverhope valley, and record deglaciation of the Fraser River.

Ice retreating to the north in Silverhope valley created a series of ephemeral proglacial lakes (Goff, 1993). Glacial Lake Silverhope attained the highest surface elevation $(1015 \mathrm{~m})$, and spilled across Hicks Pass on the Skagit crest into Chilliwack valley via Post Creek (Fig. 5B). To create a lake this deep, both Skagit valley and lower Silverhope Creek would have to have been blocked by ice (Fig. 6). Stratigraphic relationships between outburst flood deposits and wood-bearing fluvial sand near the mouth of Slesse Creek in lower Chilliwack valley led Clague and Luternauer (1982) to conclude that this event occurred about $13.5 \mathrm{ka}$ (Fig. 5C). If this age estimate for the Post Creek outburst flood is correct, then either ice persisted to block Skagit Gorge until after the 13.6 ka deglaciation of Thunder Lake, or the outburst flood occurred a few centuries before $13.5 \mathrm{ka}$. The age of other landforms created during deglaciation of these valleys have not been determined, but the ages listed in Table 2 provide some limits.

\subsection{Lower Skagit, Nooksack, and Chilliwack Valleys}

The pattern of deglaciation in the west-slope valleys of the North Cascades differed in several ways from the recession of ice from interior and east-slope valleys. Early retreat of the Puget Lobe opened the drainage of west-side valleys, including the Snoqualmie and Skykomish, which had been blocked by ice and large moraine embankments (Fig. 1; Booth, 1986b). These valleys then drained into glacial lakes Russell and Bretz (Bretz 1910).

North Fork Stillaguamish, Skagit and Nooksack valleys were all inundated from two directions by the CIS, leading to complex ice flow patterns and the development of inter-lobate zones (Fig. 5C). Deglaciation of these valleys was also directly influenced by rapid deglaciation over northern Puget Sound and by a brief incursion of marine water. Rapid destruction of the CIS over northern Puget Sound after the opening of the Straits of Juan de Fuca left a higher ice surface in the mountains to the east, and a reorientation of flow from north-south to east-west (Thorson, 1980). Ice then began to flow out of the Skagit and Nooksack valleys. Reorientation of flow is reflected in the topography of islands in northern Puget Sound, where strong subglacial flutings oriented south were overprinted by faint cross-cutting topography oriented southwest (Polenz et al., 2005).

Marine water flooded the lower Skagit valley to elevations of $110 \mathrm{~m}$ by $13.8 \mathrm{ka}$, and the Nooksack valley to $150 \mathrm{~m}$ by $13.3 \mathrm{ka}$ (Fig. 5C; Dethier et al., 1995; Dragovitch et 
al., 1999; Kovanen and Easterbrook 2001). The marine limit is marked by glaciomarine drift containing shells and by small deltas at the shoreline elevation that vary in texture from sand to gravel (Dragovitch et al., 1999; Riedel, 2011). A Skagit valley moraine at Hamilton and a North Fork Nooksack valley moraine near Kendall are close to the marine limit, and may represent locations where valley remnants of the ice sheet grounded as the land isostatically emerged and sediment filled the valley. Ages of these moraines have not been determined directly, however, and they may represent still-stands driven by topography and/or climate. The marine incursion into the lower mountain valleys was brief because most isostatic uplift occurred within the first several centuries after deglaciation (Clague and James, 2002).

Emergence of the landscape set the stage for frontal retreat of isolated masses in the Skagit, Nooksack, and Chilliwack valleys and deposition of moraines and extensive outwash fills. Most of the end moraines and kame terraces shown in Fig. 5C contain erratic rocks from British Columbia that indicate they were built by remnants of the ice sheet as they flowed down the mountain valley. Moraines in the upper Skagit valleys occur intermittently across $1400 \mathrm{~m}$ in elevation, but the majority were deposited at elevations ranging from 300 to $1200 \mathrm{~m}$ (Riedel and Probala, 2005). The moraines are prominent landforms common at valley junctions, and are often accompanied by ice marginal channels and kame terraces. Three end moraines in lower Skagit valley have been identified near the towns of Hamilton and Concrete and at the mouth of Illabot Creek (Fig. 5C; Riedel, 2011). The ages of these moraines can be roughly constrained by deglaciation at nearby sites to sometime after $13.8 \mathrm{ka}$. Skagit River tributaries at higher elevations, including Baker River and Bacon Creek, also contain evidence of several recessional moraines (Fig. 5C).

Evidence indicates that the middle Skagit valley near Newhalem was deglaciated as ice lingered up and down valley (Fig. 6). Ice cover in Skagit Gorge was limited because it is a narrow opening through the Skagit crest, and the breached divide was deglaciated

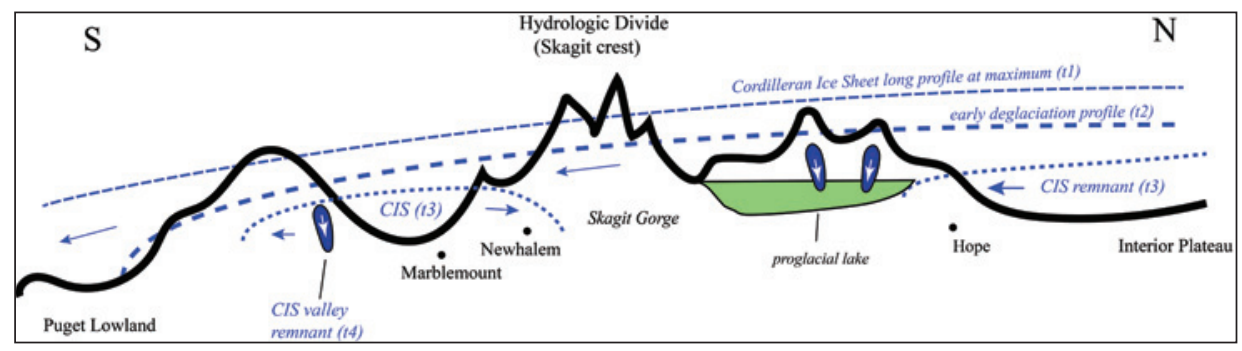

Figure 6. Schematic north-south topographic profile through the North Cascades along the Skagit River depicting hypothetical longitudinal profiles of the CIS at its maximum (t1) and at three subsequent stages of decay. Time 22 occurred after $15 \mathrm{ka}$ when surface elevation lowered $\sim 200 \mathrm{~m}$ and the Skagit crest is exposed. By $\sim 14 \mathrm{ka}(\mathrm{t} 3)$ ice separated into two ice masses on either side of the Skagit crest. Short-lived proglacial lakes were trapped between receding ice tongues. At $13 \mathrm{ka}(\mathrm{t} 4)$ ice was confined to higher-elevation tributary valleys, where it persisted until $11.6 \mathrm{ka}$. Blue arrows illustrate changing ice-flow vectors as ice disintegrates. 
relatively early. Ice then retreated west down Skagit valley and was fed by an ice tongue flowing out of Bacon Creek (Fig. 5C). This ice geometry is the only plausible explanation to a mystery: the presence of Shuksan Greenschist erratics in glacial drift at Newhalem (Fig. 5C and 6). This rock type lies only west of the Straight Creek fault near Marblemount, and could only have been deposited by ice flowing up Skagit valley. This model of ice decay would also explain the unusual Post Creek flood. More research is needed to confirm this pattern of ice sheet decay in the middle reaches of the Skagit.

Proglacial lakes formed in several valleys during frontal retreat to the north. Sauk River is the only large Skagit tributary that drains north (Fig. 5C). Retreat of the ice sheet down this valley created an unnamed glacial lake and deposition of massive amounts of fine sand and silt (Tabor et al., 2002). Glacial Lake Baker was trapped in the lower Baker valley and for a short period drained west via the Lake Tyee outlet at $335 \mathrm{~m}$ to the Skagit valley (Fig. 5C; Riedel, 2011). Lake drainage shifted to a lower outlet at $252 \mathrm{~m}$ once ice retreated east of Concrete, but superimposition of the outlet on a bedrock spur allowed the lake to persist through most of the Holocene (Riedel et al., 2011).

Age control on deglaciation of the upper Skagit valley is limited to a few sites. Scott (written communication) reports that the lower Baker River valley near the mouth of Sandy Creek was deglaciated by $14.1 \mathrm{ka}$, even as ice remained in Skagit valley. The only other limiting age for deglaciation is a basal age from a core taken from Thunder Lake at 13.6 ka (Fig. 5C; Table 2; Riedel, 2011). This core contained Glacier Peak G tephra, also with an age of $13.6 \mathrm{ka}$, meaning the middle Skagit valley was deglaciated at about the same time as sites throughout the North Cascades, including the Methow and Okanogan valleys, but after lower Baker valley (Fig. 5A and B).

CIS deglaciation occurred slightly later in the Nooksack and Chilliwack valleys than the Skagit, and about the same time as the lower Fraser valley (Fig. 1; Mathewes et al., 1972; Saunders et al., 1987; Dragovitch et al., 1999; Kovanen and Easterbook, 2001). On the north side of the lower Fraser River a Marion Lake sediment core yielded a macrofossil age of $13.7 \mathrm{ka}$, the same age for deglaciation of the lower Chilliwack and Nooksack (Table 2; Fig. 5C; Mathewes, 1973; Saunders et al., 1987). Deep Kettle Bog in the lower South Fork of the Nooksack River was deglaciated about $14.5 \mathrm{ka}$ (Kovanen and Easterbrook 2001). This age was obtained from a piece of wood that has an error of 225 years, meaning the site could have become ice free as late as $14.1 \mathrm{ka}$ (Fig. 5C; Table 2; Kovanen and Easterbrook 2001). A moraine near the mouth of the Middle Fork Nooksack River was deposited on top of hummocky topography that holds Deep Kettle Bog, and slopes down to the west, indicating that a remnant of the ice sheet flowed from the upper valley.

In the Nooksack North Fork valley, the Kendall and Maple Falls moraines and associated outwash were deposited before 13.8 ka (Table 2; Easterbrook, 1963; Kovanen and Easterbrook, 2001). The Nooksack moraines were initially thought to be evidence of 40-50 km long alpine glacier systems late in MIS 2 (Fig. 5C; Kovanen and Easterbrook, 2001). They are more likely to have been deposited by remnants of the CIS because of the presence of erratic quartzite clasts in moraine till and the long distance between the moraines and valley heads (Osborn et al., 2012). Late MIS 2 alpine glacier moraines in the region are within $\sim 5 \mathrm{~km}$ of valley heads, and equilibrium 
line altitudes necessary for the glaciers to have extended $40 \mathrm{~km}$ down valley would have been similar to those of early MIS 2 alpine glaciers to the south (Fig. 7; Porter et al., 1983; Riedel et al., 2010).

In the northwestern North Cascade Range, the Chilliwack valley drains into the Fraser River and had a complex pattern of deglaciation (Fig. 1 and 5C). The lower and middle reaches of the valley were ice-free by $13.7 \mathrm{ka}$, but the lower valley was inundated during three or more re-advances of ice from Fraser Lowland (Fig. 5C; Saunders et al., 1987; Clague et al., 1997). Re-advances of the CIS occurred from 13.6 to $13.3 \mathrm{ka}$, and from 12.9 to $12.0 \mathrm{ka}$ (Kovanen, 2002). These advances occurred in the Allerød and Younger Dryas Chronozones, and at about the same time as alpine glaciers advanced from cirques in the North Cascades (Table 1; Clague et al., 1997). Age control is limited, but it appears that remnants of the ice sheet in many North Cascade valleys stabilized to build large end moraines at this time as well. Sediments that impound Chilliwack Lake include Post Creek outburst flood gravel deposited against an end moraine. The moraine has a steep ice-contact face against the $114 \mathrm{~m}$ deep lake, and is located about $30 \mathrm{~km}$ below the head of the valley. The moraine is at a similar elevation as moraines in the nearby Depot and Silver creek valleys.

Late glacial advances of the CIS across Fraser Lowland temporarily blocked drainage in the lower Chilliwack and Nooksack valleys and caused valley floor aggradation (Fig. 5C; Saunders et al. 1987). In the middle Chilliwack valley, the outwash train extends from the Chilliwack Lake moraine and grades into lacustrine deposits in the lower valley

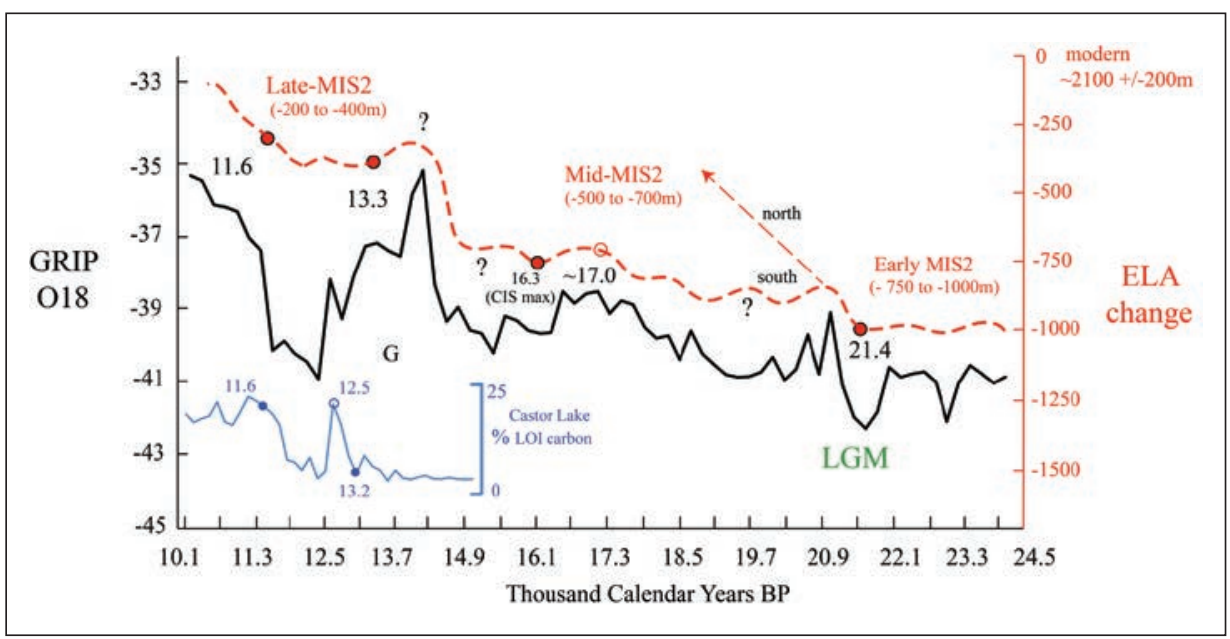

Figure 7. Proxy indicators of MIS 2 climate change after the LGM, including Greenland Ice Core O18 isotope ratio per mil (GRIP; black; Dansgaard et al., 2003), alpine glacier ELAs (red; Porter et al., 1983; Riedel et al., 2010), and in lower left Castor Lake carbon loss on ignition (blue; M.A. Abbott, personal communication). Solid dots indicate radiocarbon age control and open circles cosmogenic surface exposure or other age estimate. After about 21 ka the CIS influenced climate and raised the ELAs of alpine glaciers in the north. Glacier Peak tephra eruption at $13.6 \mathrm{ka}(\mathrm{G})$. 
(Clague and Luternauer, 1982). The blocked valleys drained to the south, where they flowed over a divide into the Samish River (Fig. 5C; Easterbrook, 1963; Saunders et al., 1987; Clague et al., 1997; Kovanen and Easterbrook, 2001). Waters from the combined rivers deposited a large gravel delta as it entered the Skagit marine embayment sometime from 13.6 to $13.3 \mathrm{ka}$ (Kovanen, 2002).

\section{Climate Change}

Late Pleistocene changes in alpine glacier equilibrium line altitudes (ELAs) provide a sensitive index of climate change (Fig. 7). The ELA of alpine glaciers is controlled by annual precipitation and summer air temperature (Ohmura et al., 1992; Leonard, 1989, 2007). Figure 8 depicts the modern and LGM climate envelopes for alpine glaciers in the North Cascades at their ELAs. The ellipses define spatial variability in ELA of $\pm 200 \mathrm{~m}$ during modern and late glacial times, caused by differences in aspect, hypsometry, and the strong west-to-east climate gradient in the region. Larger adiabatic lapse rates on the more arid eastern slope reduce ELA sensitivity (Porter, 1977; Ohmura et al., 1992; Porter and Swanson, 2008; Riedel et al., 2010).

The North Cascade ELA record is not continuous, but generally follows an unbroken record of changes in the oxygen isotope record of climate from the Greenland Ice Core Project (GRIP; Fig. 7; Dansgaard et al., 1993). Alpine valley glacier steady-state ELAs were approximately 750 to 1000 m below modern regional ELAs from 25.0 to $21.4 \mathrm{ka}$ (Porter, 1976; Riedel et al., 2010). Paleo-environmental reconstructions indicate that at this time mean summer temperature was 6 to $7{ }^{\circ} \mathrm{C}$ cooler and precipitation about $40 \%$ less than today (Heusser, 1977; Grigg and Whitlock, 2002; Marshall et al., 2004; Riedel, 2007; Bartlein et al., 2011). The summer temperature at the ELA of the LGM glaciers was similar to that found at modern glacial ELAs because of a $1000 \mathrm{~m}$ ELA depression and $6.5^{\circ} \mathrm{C} / \mathrm{km}$ adiabatic lapse rate. Thus, mean summer temperature and precipitation $(1600 \mathrm{~mm})$ at the ELA of North Cascade glaciers during the LGM was similar to that found today at the ELA of Peyto Glacier in the Canadian Rockies (Fig. 8; Leonard, 1989; Ohmura et al., 1992).

Climate warming after $21.4 \mathrm{ka}$ caused a rise in ELA and widespread retreat of alpine glaciers in the northernmost North Cascades until at least $20 \mathrm{ka}$ (Fig. 7; Cary and Carlston, 1937; Mackin, 1941; Hicock and Lian, 1995; Riedel et al., 2010). The retreat of the cirque-based valley glaciers in the north was likely accelerated by increased aridity caused by katabatic winds off of the continental ice sheet (Grigg and Whitlock, 2002; Marshall et al., 2004; Thackray, 2001, 2008). Isostatic depression of the land surface by the $1500 \mathrm{~m}$ thick CIS may have also effectively raised ELAs of alpine glaciers. In lowlands to the west isostatic depression was several hundred meters (Clague and James, 2002). Persistent influence of the CIS on precipitation during ice ages is also evident in the Rocky Mountains $500 \mathrm{~km}$ to the east, where cirque floors in northern Montana are $\sim 100$ m higher than those farther to the south (Locke, 1990).

During full ice sheet glaciation at $16.3 \mathrm{ka}$ the surface of the ice sheet was 20002200 m elevation over the North Cascades crest, well above the elevation of most cirque floors in the region. Steady-state ELAs for Hyak I and Rat Creek moraines in 


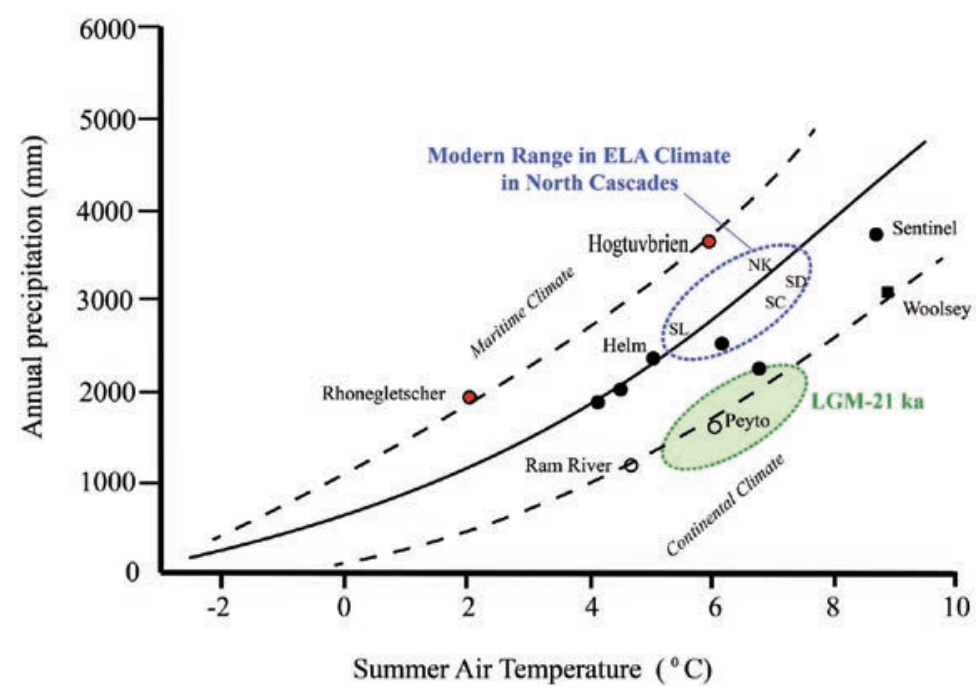

Figure 8. Climate at the equilibrium line altitude of modern glaciers. Solid curve depicts best fit for 70 modern glaciers (circles and squares-not all shown) and dashed lines the modern glacier climate envelope after Ohmura et al. (1992) and Leonard (2007). Blue ellipse depicts approximate climate space of modern North Cascade glaciers $(N K=$ North Klawatti, $S C=$ South

Cascade; $S L=$ Silver; $S D=$ Sandalee). Green ellipse shows climate at glacier ELAs from 25-21.4 ka assuming a $\sim 40 \%$ reduction in annual precipitation and a $\sim 6.5^{\circ} \mathrm{C}$ drop in summer temperature. Summer air temperature at glacial ELAs did not change during LGM as ELA dropped $1000 \mathrm{~m}$.

the south were 500-700 m lower than today (Fig. 3 and 7; Porter, 1976; Porter et al., 1983; Porter and Swanson, 2008). Heusser (1977) used pollen assemblages to estimate that mean July temperature on the Pacific slope of the Cascades during mid MIS 2 was $\sim 4{ }^{\circ} \mathrm{C}$ cooler than today, similar to estimates from calibrated climate models (Fig. 7; Kutzbach, 1987).

After the main stage of ice sheet glaciation, alpine glaciers advanced in the interval from 13.7 to $11.6 \mathrm{ka}$ to build a series of moraines within $5 \mathrm{~km}$ of valley heads. This advance was driven by a $200-400 \mathrm{~m}$ drop in ELA that was slightly larger than the maximum Holocene advance during the Little Ice Age, but smaller than during mid MIS 2 Rat Creek and Hyak I advances (Fig. 4 and 7; Riedel, 2007; Osborn et al., 2012). It is uncertain what combination of temperature and precipitation led to this alpine glacier advance. In the western part of the range the late glacial advances were slightly larger than maximum Neoglacial advances. In the east they were smaller than the extent of late $20^{\text {th }}$ century glaciers (Waitt, 1979). Had increased precipitation been a major factor, alpine glaciers would likely have been larger in cirques in the eastern North Cascades. Mathewes (1993) suggested that the Younger Dryas cold period was more severe in maritime areas in this region. If increased accumulation was not a factor, mean July temperature during late MIS 2 glacial advances was $2-3{ }^{\circ} \mathrm{C}$ colder than today (Heusser, 1977; Kutzbach, 1987; Mathewes, 1993; Carlson, 2013). 
Retreat of the ice sheet and late glacial activity of alpine glaciers from 21.4 to $11.6 \mathrm{ka}$ were influenced by millennial-scale climate fluctuations that led to deposition of multiple moraines in many valleys (Porter, 1976; Waitt and Thorson, 1983; Riedel, 2007; Porter and Swanson, 2008). Millennial-scale climate fluctuations are also reflected in other climate proxy records in this region, including pollen and macrofossil records (Grigg and Whitlock, 2002; Riedel, 2007b; Jimenez-Moreno et al. 2010). Several authors have related these perturbations to Bond Cycles of climate change in the North Atlantic, linking climate changes at the end of MIS 2 between the two hemispheres (Bond et al., 1993; Dansgaard et al., 1993; Clark and Bartlein, 1995; Hicock et al., 1999; Thackray, 2008).

\section{Conclusion}

Deglaciation of the North Cascades during MIS 2 was complex, and included the retreat of alpine glaciers and a continental ice sheet. South of the ice sheet terminus, retreat of 30-40 km-long alpine valley glaciers left five or more moraines from 21.4 to $11.6 \mathrm{ka}$. Correlation of moraine age within the region and globally is limited by the small number of moraines with accurate age estimates. Synchronous advances were associated with millennial-scale climate fluctuations that occurred throughout MIS 2, and these fluctuations generally follow changes in isotopic composition of the Greenland ice core.

Advance of the Cordilleran Ice Sheet to its maximum occurred $~ 5,000$ years after the LGM and the MIS 2 alpine glacier maximum. Ice sheet retreat began a few centuries after reaching its maximum extent at $16.3 \mathrm{ka}$, and early lowering of the ice sheet surface stranded large masses of ice in deep valleys even as cirques were also being deglaciated. Deglaciation then occurred rapidly by downwasting over a wide area, and most of the valleys became ice-free from 14.5 to $13.5 \mathrm{ka}$, although ice sheet remnants probably persisted for several centuries in some valleys. Rapid deglaciation was slowed by climate fluctuations, and at least one large recessional moraine and many smaller lateral moraines and kame terraces were deposited in most valleys. Rapid decay of the ice sheet led to formation of deep proglacial lakes and widespread evidence of large volumes of glacial meltwater drainage through the mountains. The ice sheet and alpine cirque glaciers advanced relatively short distances between 13.7 and $11.6 \mathrm{ka}$.

\section{References}

Abbott, M.B. 2016. Data from lake sediment cores in Methow and Okanogan valley lakes. Written communication, University of Pittsburgh.

Armstrong, J.E., Crandell, D.R., Easterbrook, D.J., Noble, J.B. 1965. Late Pleistocene stratigraphy and chronology in southwestern British Columbia and northwestern Washington. Geological Society of America Bulletin 76, 321-330.

Barksdale, J.D. 1941. Glaciation of the Methow Valley, Washington. Journal of Geology 49 (7), 721-737. http://www.jstor.org/stable/30082302.

Barnosky, C.W., Anderson, P.M., Bartlein, P.J. 1987. The northwestern U.S. during deglaciation: Vegetational history and paleoclimatic implications. In: W.F. Ruddiman, H.E. Wright, Jr (Eds.), North America and Adjacent Oceans during the Last Deglaciation. Geological Society of America, The Geology of North America K-3, pp. 289-321.

Bartlein, P., Harrison, S., Brewer, S., Connor, S., Davis, B., Gajewski, Guiot, J., Harrison-Prentice, T., Henderson, A., Peyron, O., Prentice, I.C., Schloze, M., Seppaa, H., Shuman, B., Sugita, 
S., Thompson, R.S., Viau, A.E., Williams, J., Wu, H. 2011. Pollen-based continental climate reconstructions at 6 and 21ka: a global synthesis. Climate Dynamics 37, 775-802. http://doi. org/10.1007/s00382-010-0904-1.

Bilderback, E.L., Clark, D.H. 2003. Timing and paleoclimatic significance of latest Pleistocene and Holocene cirque glaciation in the Enchantment Lakes basin, North Cascades, Washington, U.S.A. XVI INQUA Congress Programs with Abstracts, p. 163.

Bond, G., Broecker, W., Johnsen, S., McManus, J., Lagey-Rie, L., Jouzel, J., Bonani, G. 1993. Correlations between climate records from North Atlantic sediments and Greenland Ice. Nature 365, 143-47. http://doi.org/10.1038/365143a0.

Booth, D.B. 1986a. The formation of ice-marginal embankments into ice-dammed lakes in the eastern Puget Lowland, Washington, U.S.A., during the late Pleistocene. Boreas 15, 247-263. http://doi.org/10.1111/j.1502-3885.1986.tb00929.x.

Booth, D.B. 1986b. Mass balance and sliding velocity of the Puget Lobe of the cordilleran Ice sheet during the last glaciation. Quaternary Research 25, 269-280. http://doi.org/10.1016/00335894(86)90001-3.

Booth, D.B., Troost, K.G., Clague, J.J., Waitt, R.B. 2004. The Cordilleran Ice Sheet. In: A.R. Gillespie, S.C. Porter, B.F. Atwater (Eds.), The Quaternary Period in the United States. Elsevier Developments in Quaternary Science, pp. 105-126.

Bretz, J.H. 1910. Glacial lakes of Puget Sound. Journal of Geology 18, 448-458.

Bronk Ramsey, C. 2009. Bayesian analysis of radiocarbon dates. Radiocarbon 51 (1), 337-360.

Carlson, A.E. 2013. The Younger Dryas climate event. The Encyclopedia of Quaternary Science $3,126-134$.

Cary, A.S., Carlston, C.N. 1937. Notes on Vashon glaciation of the south fork Skykomish River valley, Washington. Northwest Science 11, 61-62.

Clark, P.U., Bartlein, P.J. 1995. Correlation of late Pleistocene glaciation in the western United States with North Atlantic Heinrich events. Geology 23 (6), 483-486.

Clague, J.J. 1983. Glacio-isostatic effects of the Cordilleran Ice Sheet, British Columbia, Canada. In: D.E. Smith, A.G. Dawson (Eds.), Shorelines and Isostasy. Academic Press, London, pp. 321-343.

Clague J.J. 1986. The Quaternary stratigraphic record of British Columbia - evidence for episodic sedimentation controlled by glacial erosion. Canadian Journal of Earth Sciences 23, 885894. http://doi.org/10.1139/e86-090.

Clague, J.J. 1989. Quaternary geology of the Canadian Cordillera. In: R.J.Fulton (Ed.), Quaternary Geology of Canada and Greenland. Geological Survey of Canada, $195 \mathrm{pp}$.

Clague, J.J., Armstrong, J.E., Mathews, W.H. 1980. Advance of the late Wisconsin Cordilleran Ice Sheet in southern British Columbia since 22,000 yr B.P. Quaternary Research 13, pp. 322326. http://doi.org/10.1016/0033-5894(80)90060-5.

Clague, J.J., Luternauer, J.L. 1982. Excursion 30A: Late Quaternary Sedimentary Environments, Southwestern British Columbia. International Association of Sedimentologists, $11^{\text {th }}$ International Congress on Sedimentology Excursion Guidebook, Hamilton, Ontario.

Clague, J.J., Mathewes, R.W., Guilbault, J.-P., Hutchinson, I., Ricketts, B.D. 1997. Pre-Younger Dryas resurgence of the southwestern margin of the Cordilleran ice sheet, British Columbia, Canada. Boreas 26, 261-277. http://doi.org/10.11/j.1502-3885.1997.tb00855.x.

Clague, J.J., James, T.S. 2002. History and isostatic effects of the last ice sheet in southern British Columbia. Quaternary Science Reviews 21, 71-87. http://doi.org/10.1016/S02773791(01)00070-1.

Clague, J. J., Ward, B. 2011. Pleistocene glaciation of British Columbia. Developments in Quaternary Science 15, 563-573. http://doi.org/10.1016/8978-0-444-53447-7.00044-1.

Crandell, D.R. 1965. The glacial history of western Washington and Oregon. In: H.E. Wright, Jr., D.G. Frey (Eds.), The Quaternary of the United States. Princeton, Princeton University Press, pp. 341-353. 
Daly, R.A. 1912. Geology of the North American Cordillera at the forty-ninth parallel. Geological Survey of Canada Memoir 38, 857 pp.

Dansgaard, W., Johnsen, S.J., Clauson, H.B., Dahl-Jensen, D., Gundestrup, N.S., Hammer, C.U., Hvidberg, C.S., Steffensen, J.P., Sveinbjornsdottir, A.E., Jouzel, J. 1993. Evidence for general instability of past climate from a 250-kyr ice-core record. Nature 364, 218-220. http://doi. org/10.1038/364218a0.

Dawson, W.L. 1898. Glacial phenomena in Okanogan County, Washington. American Geologist 22, 203-217.

Davis, N.F.G., Mathews, W.H. 1944. Four phases of glaciation with illustrations from southwestern British Columbia. Canadian Journal of Earth Sciences 12, 403-413.

Dethier, D.L., Pessl, F., Keuler, R.F., Balzarini, M.A., Pevear, D.R. 1995. Late Wisconsinan glaciomarine deposition and isostatic rebound, northern Puget Lowland, Washington. Geological Society of America Bulletin 107, 1288-1303.

Dragovich, J.D., Norman, D.K. , Grisamer, C.L., Logan, R.L., Anderson, G. 1998. Geologic map and interpreted geologic history of the Bow and Alger 7.5-minute Quadrangles, western Skagit County, Washington. Washington Division of Geology and Earth Resources Open File Report 98-5, 80 pp.

Dragovich, J.D., Norman, D.K. , Lapen, T.J., Anderson, G. 1999. Geologic map of the SedroWoolley north and Lyman 7.5-minute Quadrangles, western Skagit County, Washington. Washington Division of Geology and Earth Resources Open File Report 99-3, 37 pp.

Easterbrook, D.J. 1963. Late Pleistocene glacial events and relative sea level changes in northern Puget Lowland. Geological Society of America Bulletin 74, 1465-1483.

Easterbrook, D.J. 1976. Geologic map of western Puget Lowland and San Juan Islands, Washington. Geological Society of America Bulletin 80, 2273-2286.

Evans, I.S. 2017. Written communication on the glaciation of the Southern Coast Mountains.

Flint, R.F. 1971. Glacial and Quaternary Geology. John Wiley and Sons, 892 pp.

Friele, P.A., Clague, J.J. 2002. Younger Dryas re-advance in Squamish River valley, southern Coast Mountains, British Columbia. Quaternary Science Reviews 21, 1925-33. http://doi. org/10.1016/S0277-3791(02)00081-1.

Fulton, R.J. 1967. Deglaciation in Kamloops Region, British Columbia. Geological Survey of Canada Bulletin 154, 36 pp.

Fulton, R.J. 1991. A conceptual model for growth and decay of the Cordilleran Ice Sheet. Géographie Physique et Quaternaire 45 (3), 281-286. http://doi.org/10.7202/032875ar.

Goff, J. 1993. Late Pleistocene and Holocene Sedimentation in Silverhope Valley, British Columbia. Ph.D. thesis, University of Western Ontario, London.

Gosse, J.C., Evenson, E.B., Klein, J., Lawn, B., Middleton, R. 1995. Precise cosmogenic ${ }^{10}$ Be measurements in western North America: Support for a Younger Dryas cooling event. Geology 23 (10), 877-880.

Grigg, L.D., Whitlock, C. 2002. Patterns and causes of millennial-scale climate change in the Pacific Northwest during Marine Isotope Stages 2 and 3. Quaternary Science Reviews 21, 2067-2083. http://doi.org/10.1016/S0277-3791(02)00017-3.

Haugerud, R.A.1985. Geology of the Hozameen Group and the Ross Lake shear zone, Maslepanik area, North Cascades, southwest British Columbia. Ph.D. Thesis University of Washington, Seattle, $269 \mathrm{pp}$.

Haugerud, R.A. Hendy, I. 2016. Collapse of the Juan de Fuca Lobe of the Cordilleran Ice Sheet. Geological Society of America Abstracts with Programs. Abstract 121-8.

Heine, J.T. 1998. Extent, timing and climatic implications of glacier advances, Mount Rainier, Washington, U.S.A. at the Pleistocene Holocene transition. Quaternary Science Reviews 17, 1139-1148. http://doi.org/10.1016/S0277-3791(97)00077-2. 
Heller, P.L. 1980. Multiple ice flow directions during the Fraser Glaciation in the lower Skagit River drainage, North Cascade Range, Washington. Arctic and Alpine Research 12, 299-308.

Heusser, C.J. 1977. Quaternary palynology of the Pacific slope of Washington. Quaternary Research 8, 282-306.

Hicock, S.R., Lian, O.B. 1995. The Sisters Creek Formation: Pleistocene sediments representing a nonglacial interval in southwestern British Columbia at about 18ka. Canadian Journal of Earth Sciences 32, 758-767.

Hicock, S.R., Lian, O.B., Mathewes, R.W. 1999. 'Bond cycles' recorded in terrestrial Pleistocene sediments of southwestern British Columbia, Canada. Journal of Quaternary Science 14, 443-449.

Holmes, A. 1965. Principles of Physical Geology. Thomas Nelson Ltd., London. 1288 pp.

Jimenez-Moreno, G., Anderson, R.S., Deprat, S., Grigg, L.D., Grimm, E.C., Heusser, L.E., Jacos, B.F., Lopez-Martinez, C., Whitlock, C.L., Willard, D.A. 2010. Millenial-scale variability during the last glacial in vegetation records from North America. Quaternary Science Reviews 29, 2865-2881. http://doi.org/10.1016/j.quascirev.2009.12.013.

Kaufman, D.S., Porter, S.C., Gillespie, A.R. 2004. Quaternary alpine glaciation in Alaska, the Pacific Northwest, Sierra Nevada and Hawaii. In: A.R. Gillespie, S.C. Porter, B.F. Atwater (Eds.), The Quaternary Period in the United States. Elsevier Developments in Quaternary Science 1, pp.77-103. http://doi.org/10.1016/S1571-0866(03)01005-4.

Kiver, E.P. 1974. Holocene glaciation in the Wallowa Mountains, Oregon. In: W.C. Mahaney (Ed.), Quaternary Environments: Proceedings of a Symposium. York University Geographical Monographs 5, pp. 169-195.

Kovanen, D.J. 2002. Morphologic and stratigraphic evidence for Allerød and Younger Dryas age glacier fluctuations of the Cordilleran Ice Sheet in British Columbia, Canada and northwestern Washington, U.S.A. Boreas 31, 163-184. http://doi.org/10.111/j.1502-3885.2002.tb01064.x.

Kovanen, D.J., Easterbrook, D.J. 2001. Late Pleistocene, post-Vashon, alpine glaciation of the Nooksack drainage, North Cascades, Washington. Geological Society of America Bulletin 113, 274-288.

Kovanen, D.J., Slaymaker, O.V. 2004 Glacial imprints of the Okanogan Lobe, southern margin of the Cordilleran Ice Sheet. Journal of Quaternary Science 19 (60), 547-565. http://doi. org/10.1002/jqs. 855 .

Kovanen,D.J., Slaymaker, O. 2005. Fluctuations of the Deming Glacier and theoretical equilibrium line altitudes during the Late Pleistocene and early Holocene on Mount Baker, Washington, USA. Boreas 34, 157-175. http://doi.org/10.1111/j.1502-3885.2005.tb01012.x.

Kuehn, S.C., Froese, D.G., Carrara, P.E., Foit, F.F. Jr., Pearce, N.J.G., Rotheisler, P. 2009. Majorand trace-element characterization, expanded distribution, and a new chronology for the latest Pleistocene Glacier Peak tephras in western North America. Quaternary Research 71, 201-216. http://doi.org/10.1016/j.yqres.2008.11.003.

Kutzback, J.E.1987. Simulations of climatic patterns during the deglaciation of North America. In: W.F. Ruddiman, H.E. Wright (Eds.), Decade of North American Geology, Geological Society of America, pp. 425-446.

Leonard E.M. 1989. Climatic change in the Colorado Rocky Mountains: Estimates based on modern climate at late Pleistocene equilibrium lines. Arctic and Alpine Research 22, 1-13.

Leonard E.M. 2007. Modeled patterns of Late Pleistocene glacier inception and growth in the Southern and Central Rocky Mountains, USA: sensitivity to climate change and paleoclimatic implications. Quaternary Science Reviews 27, 2152-2166. http://doi.org/10.1016/j. quascirev.2007.02.013.

Lian, O.B., Mathewes, R.W., Hicock, S.R. 2001. Paleo-environmental reconstruction of the Port Moody interstade, a nonglacial interval in southwestern British Columbia at about $18,000{ }^{14} \mathrm{C}$ yr B.P. Canadian Journal of Earth Sciences 38, 943-952. http://doi.org/10.1139/e00-114. 
Locke, W.W. 1990. Late Pleistocene glaciers and the climate of western Montana, U.S.A. Arctic and Alpine Research 22, 1-13.

Lowdon, J.A., Fyles, J.G., Blake, W. Jr. 1967. Geological Survey of Canada radiocarbon dates VI. Radiocarbon 9, 156-197.

Mack, R.N., Rutter, N.W.,Valastro, S. 1979. Holocene vegetation history of Okanogan valley, Washington. Quaternary Research 12, 212-225. http://doi.org/10.1016/0033-5894(79)90058-9.

Mackin, J.H. 1941. Glacial geology of the Snoqualmie-Cedar area, Washington. Journal of Geology 49, 449-481.

Margold, M., Jansson, K.N., Kleman, J., Streoven, A.P., Clague, J.J. 2013. Retreat pattern of the Cordilleran Ice Sheet in central British Columbia at the end of the last glaciation reconstructed from glacial meltwater landforms. Boreas 42, 830-848. http://doi.org/10.1111/bor.12007.

Marshall, S.J., Pollard, D., Hostettler, S., Clark, P.U. 2004. Coupling ice-sheet and climate models for simulation of former ice sheets. In: A.R. Gillespie, A.R., Porter, S.C., Atwater, B.F. (Eds.), The Quaternary Period in the United States. Elsevier Developments in Quaternary Science (1), pp. 117-143.

Mathews, W.H. 1968. Geomorphology of Lightning Creek valley, Manning Park, southwest B.C. Syesis 1, 65-78.

Mathewes, R.W. 1973. A palynological study of postglacial vegetation changes in the University research Forest. Canadian Journal of Botany 51, 2085-2103.

Mathewes, R.W. 1993. Evidence for Younger Dryas-age cooling on the North Pacific Coast of America. Quaternary Science Reviews 12, 321-331. http://doi.org/10.1016/0277-3791(93)90040-S.

Mathewes, R.W., Borden, C.E., Rouse G.E. 1972. New radiocarbon dates from the Yale area of lower Fraser River Canyon, British Columbia. Canadian Journal of Earth Sciences 9, 1055-57.

Mitchell. S.G., Montgomery, D.R. 2006. Influence of a glacial buzzsaw on the height and morphology of the Cascade Range in central Washington, U.S.A. Quaternary Research 65, 96-107. http://doi.org/10.1016/j.yqres.2005.08.018.

National Park Service. Unpublished sub-bottom survey of the bed of Lake Chelan. Available from North Cascades National Park Geologist, Sedro-Woolley, Washington.

Ohmura, A., Kasser, P., Funk, M. 1992. Climate at the equilibrium line of glaciers. Journal of Glaciology 38, 397-411. http://doi.org/10.1017/S00222143000002276.

Osborn, G., Menounous, B., Ryane, C., Riedel, J., Clague, J., Koch, J., Clark, D., Scott, K., Davis, P.T. 2012.Latest Pleistocene and Holocene Glacier Fluctuations on Mount Baker, Washington. Quaternary Science Reviews 49, 33-51. http://doi.org/10.1016/j.quascirev.2012.06.004.

Polenz, M., Slaughter, S.L., Thorsen, G.W. 2005. Geologic Map of the Coupeville and part of the Port Townsend North 7.5 minute Quadrangles, Island County, Washington. Washington Division of Geology and Earth Resources Geologic Map GM-58.

Porter, S.C. 1976. Pleistocene glaciation in the southern part of the North Cascade Range, Washington. Geological Society of America Bulletin 87, 61-75.

Porter, S.C. 1977. Present and past glaciation threshold in the Cascade Range, Washington, U.S.A.: Topographic and climatic controls, and paleoclimatic implications. Journal of Glaciology 18, 101-116. http://doi.org/10.1017/S0022143000021559.

Porter, S.C. 1978.Glacier Peak tephra in the North Cascade Range, Washington: Stratigraphy, distribution, and relationship to late glacial events. Quaternary Research 10, 30-41. http:// doi.org/10.1016/0033-5894(78)90011-X.

Porter, S.C. 2004. Glaciation of western Washington, U.S.A. In: J. Ehlers, P.L. Gibbard (Eds.), Quaternary Glaciations - Extent and Chronology, Part II. Elsevier, pp. 289-293. http://doi. org/10.1016/S1571-0866(04)80204-5.

Porter, S.C., Pierce, K.L., Hamilton, T.D. 1983. Late Wisconsin mountain glaciation in the Western United States. In: S.C. Porter (Ed.), Late-Quaternary Environments, Vol. 1, The Late Pleistocene. University of Minnesota Press, Minneapolis, MN, pp. 71-111. 
Porter, S.C., Swanson, T.W. 1998. Radiocarbon age constraints on rates of advance and retreat of the Puget lobe of the Cordilleran Ice Sheet during the last glaciation. Quaternary Research 50, 205213. http://doi.org/10.1006/qres.1998.2004.

Porter, S.C., Swanson, T.W. 2008. ${ }^{36} \mathrm{Cl}$ dating of the classic Pleistocene glacial record in the northeastern Cascade Range, Washington. American Journal of Science 308, 130-166. http://doi. org/10.2475/02.2008.02.

Prest, V.K., Grant, D.R., Rampton, V.N. 1968. Glacial Map of Canada. Geological Survey of Canada, Map 1253A.

Ragan, D.M. 1961. Physiographic map of the Northwestern North Cascades. Unpublished map Department of Geology, Arizona State University, Tempe.

Reasoner, M.A., Osborn, G., Rutter, N.W. 1994. Age of the Crowfoot advance in the Canadian Rocky Mountains: A glacial event coeval with the Younger Dryas oscillation. Geology 22, 439-442.

Riedel, J.L. 2007. Late Pleistocene glacial and environmental history of Skagit valley, Washington and British Columbia. Ph.D. Thesis Simon Fraser University. Vancouver, 187 pp.

Riedel, J.L. 2015. Geologic constraints on the geometry of the Cordilleran Ice Sheet in Skagit Valley during marine isotope stage 2. Geological Society of America Abstracts with Programs, Vancouver.

Riedel, J.L. 2011. Quaternary Geology of Skagit Valley, Washington. Unpublished Pacific Northwest Cell Friends of the Pleistocene Field Trip Guidebook, 51 pp.

Riedel, J.L., Probala, J. 2005. Mapping ecosystems at the landform scale in Washington State. Park Science 23 (4), 37-42.

Riedel, J.L., Haugerud, R.A., Clague, J.J. 2007. Geomorphology of a Cordilleran Ice Sheet drainage network through breached divides in the North Cascades Mountains of Washington and British Columbia. Geomorphology 91, 1-18. http://doi.org/10.1016/j.geomorph.12007.01.021.

Riedel, J.L., Clague, J.J., Ward, B.C. 2010. Timing and extent of early marine oxygen isotope stage 2 alpine glaciation in Skagit valley, Washington. Quaternary Research 73 (2), 313-323. http://doi. org/10.1016/j.yqres.2009.10.004.

Riedel, J.L., Tucker, D.S., Scott, K.M. 2011. Late Glacial and Holocene History of Baker River valley, Washington. Geological Society of America Abstracts with Programs. Minneapolis.

Ryder, J.M. 1989. Glacial history of the southern Okanagan Range British Columbia. CANQUA Abstracts with Programs, Edmonton.

Ryder, J.M., Fulton, R.J., Clague, J.J. 1991. The Cordilleran Ice Sheet and the glacial geomorphology of southern and central British Columbia. Geographie Physique et Quaternaire 45 (3), 365-377. http://doi.org/10.7202/032882ar.

Runner, J.J. 1921, Origin and history of Lake Chelan. Geological Society of America Bulletin 32, 87-88.

Saunders, I.R., Clague, J.J., Roberts, M.C. 1987. Deglaciation of Chilliwack River valley, British Columbia. Canadian Journal of Earth Science 24, 915-923. http://doi.org/10.1139/e87-089.

Scott, K.M. Postglacial geology of Mount Baker Volcano, North Cascades, Washington. Written communication.

Simon-Labric, T., Brocard, G.Y., Teyssier, C., van der Beek, P.A., Reiners, P.W., Shuster, D.L., Murray, K.E., Whitney, D.L. 2014. Low-temperature thermochronologic signature of range divide migration and breaching in the North Cascades. Lithosphere. Geological Society of America Data Repository Item 2014344. http://doi.org/10.1130/L382.1.

Stuiver, M., Grootes, P.M. (and many others) 1995. The GISP2 $\delta^{18} \mathrm{O}$ Climate Record of the Past 16,500 Years and the Role of the Sun, Ocean, and Volcanoes. Quaternary Research 44 (3), 341-354.

Souch, C. 1989. New radiocarbon dates for early deglaciation from the southeastern Coast Mountains of British Columbia. Canadian Journal of Earth Sciences 26, 2169-2171. http://doi.org/10.1139/e89-182.

Spooner, A.M., Brubaker, L.B. 2007. Thunder Lake: a lake sediment record of Holocene vegetation and climate history in North Cascades National Park, Washington. Unpublished Report to the National Park Service. Available from North Cascades National Park Archeologist, Sedro-Wooley, Washington. 
Tabor, R.W., Haugerud, R.A. 1999. Geology of the North Cascades: A Mountain Mosaic. The Mountaineers, Seattle, WA. 143 pp.

Tabor, R.W., Frizzel, T.A., Whetten, J.T., Waitt, R.B., Swanson, D.A., Byerly, G.R., Booth, D.B ., Hetherington, M.J., Zartman, R.E. 1987. Geologic Map of the Chelan 30 by 60 minute Quadrangle, Washington. Miscellaneous Investigations Series Map 1-1661.

Tabor, R.W., Booth, D.B., Vance, J.A., Ford, A.B. 2002. Geologic Map of the Sauk River 30 by 60 minute Quadrangle, Washington. Geologic Investigation Series I-2592.

Thackray, G.D. 2001. Extensive early and middle Wisconsin glaciation on the western Olympic Peninsula, Washington, and the variability of Pacific moisture delivery to the northwestern United States. Quaternary Research 55, 257-70. http://doi.org/10.1006/qres.2001.2220.

Thackray, G.D. 2008. Varied climatic and topographic influences on late Pleistocene mountain glaciation in the western United States. Journal of Quaternary Science 23 (6-7), 671-681. http://doi.org/10.1002/jqs.1210.

Thorson, R.M. 1980. Ice-Sheet glaciation of the Puget Lowland, Washington, during the Vashon stade. Quaternary Research 13, 303-321. http://doi.org/10.1016/0033-5894(80)90059-9.

Troost, K.G. 2016. Chronology, lithology, and paleo-environmental interpretations of the penultimate ice-sheet advance into Puget Lowland.Ph.D. Thesis. University of Washington. Seattle.

Waitt, R.B. 1972. Geomorphology and Glacial Geology of the Methow Drainage Basin, Eastern North Cascade Range, Washington. Ph.D. thesis, University of Washington, Seattle.

Waitt, R.B. 1975. Late Pleistocene alpine glaciers and the Cordilleran Ice Sheet at Washington Pass, North Cascade Range, Washington. Arctic and Alpine Research 7, 25-32.

Waitt, R.B. 1977. Evolution of glaciated topography of upper Skagit drainage basin, Washington. Arctic and Alpine Research 9, 183-192.

Waitt, R.B. 1979. Rockslide-avalanche across a distributary lobe of the Cordilleran Ice Sheet in the Pasayten Valley, Northern Washington. Arctic and Alpine Research 11,33-40.

Waitt, R.B., Davis, P.T. 1988. No evidence for post ice-sheet cirque glaciation in New England. American Journal of Science 288, 495-533.

Waitt, R.B., Thorson, R.M. 1983. The Cordilleran Ice Sheet in Washington, Idaho, and Montana. In: S.C. Porter (Ed.), Late-Quaternary Environments of the United States, Vol. 1, The Late Pleistocene. University of Minnesota Press, Minneapolis, pp. 54-70.

Waitt, R.B., O'Connor, J.E., Benito, G. 1994. Scores of gigantic, successively smaller Lake Missoula floods through channelled scabland and Columbia valley. In: D.A. Swanson, R.A. Haugerud (Eds.), Geologic field trips in the Pacific Northwest Volume. Department of Geological Sciences University of Washington.

Waters, A.C. 1933. Terraces and Coulees along the Columbia River near Lake Chelan, Washington. Geological Society of America Bulletin, 44 (4), 783-820. http://doi. org/10.1130/GSAB-44-783.

Whetten, J.T. 1967. Lake Chelan, Washington: bottom and sub-bottom topography. Limnology and Oceanography 12 (2), 253-259.

Wilson, J.T., Falconer, G., Mathews, W.H., Prest, V.K. (compliers). 1958. Glacial Map of Canada. Geological Association of Canada, Toronto.

Zielinski, G.A., Davis, P.T. 1987. Late Pleistocene age of the type Temple Lake moraine, Wind River Range, Wyoming, U.S.A. Géographie Physique et Quaternaire 41 (3), 397-401 . http:// doi.org/10.7202/032695ar. 